\title{
El vecino. Historias. Desplazando el significado de los superhéroes
}

\author{
El vecino. Historias. \\ Shifting superberoes' meaning \\ Juan Carlos Pérez García \\ (Pepo PÉrez) \\ Universidad de Málaga
}

Pepo Pérez (1969) es licenciado en Derecho, y graduado y doctor en Bellas Artes por la Universidad de Málaga, donde es profesor. Coautor junto a Santiago García de las novelas gráficas El vecino (Astiberri, desde 2004; adaptada a serie televisiva para Netflix en 2019), ha publicado historietas en medios como NSLM, El Manglar, Rockdelux o El Estafador. Ha sido visiting scholar en la School of Visual Arts de Nueva York (2013) y dibujante residente en La Maison des Auteurs de Angoulême (2014). Como crítico y estudioso del cómic ha publicado en medios de prensa, en revistas académicas y en libros teóricos. También ha coordinado los libros colectivos Cómic digital hoy (2016) y Enseñar el arte. Seis experiencias desde la universidad (2019), y organizado cursos universitarios de verano como Tendencias recientes en el cómic y la novela gráfica (2016). Ha comisariado la exposición colectiva Premio Nacional de Cómic. 10 años. 2007-2017 y expuesto su propio trabajo en muestras individuales y colectivas.

Fecha de recepción: 8 de septiembre de 2020

Fecha de aceptación definitiva: 31 de octubre de 2020 


\title{
Resumen
}

El vecino. Historias (2019) es una novela gráfica de Santiago García y Pepo Pérez. Forma parte de la serie El vecino (2004-hoy), desarrollada en formatos y tonos narrativos variables; su argumento parte del contraste entre dos mundos, el cotidiano (la vida corriente de unos vecinos) y el fantástico (uno de ellos es un superhéroe). El vecino. Historias recopila historias cortas cuyas estrategias artísticas son analizadas en este ensayo. Cada una plantea diferentes juegos formales y tonales, a menudo desde perspectivas metalingüísticas que cuestionan las convenciones y formatos del cómic. También se exploran los significados ideológicos implícitos en los códigos de superhéroes.

Palabras clave: comic book, lenguajes del cómic, novela gráfica española, tiras de prensa, superhéroes.

\begin{abstract}
El vecino. Historias (2019) is a graphic novel by Santiago García and Pepo Pérez. El vecino (2004-today) is a comic series developed in variable narrative formats and tones, which serve as a vehicle for a plot arising from the contrast between the worlds of the everyday (i.e. the ordinary life of some neighbors) and the fantastic (as one of them is a superhero). The artistic strategies of the short stories collected in El vecino. Historias are analyzed in this essay. Each one displays different formal and tonal games, often from metalinguistic perspectives that question the conventions and formats of comics. The ideological meanings that are implicit in superhero codes are also explored in this compilation and thus also on this paper.
\end{abstract}

Keywords: comic book, comic-strip, languages of comics, Spanish graphic novels, superheroes.

\section{Cita bibliográfica}

Pérez García, J. C. «El Vecino. Historias. Desplazando el significado de los superhéroes», en CuCo, Cuadernos de cómic n. ${ }^{\circ} 15$ (2020), pp. 71-108. 


\section{Introducción. El vecino como serie de cómic}

El vecino. Historias (García y Pérez, 2019) es una novela gráfica que el autor de este texto ha realizado junto con el guionista Santiago García. Forma parte de un proyecto de largo recorrido que comenzó con el primer tomo de El vecino (2004) y se ha desarrollado con El vecino 2 (2007), El vecino 3 (2009) y un cuarto y quinto en proceso de realización. Una serie de cómic desarrollada en diversos formatos y tonos narrativos y visuales, siempre con un afán de experimentación formal (FIG. 1). La premisa de El vecino parte del choque deliberado entre dos mundos, el cotidiano y el fantástico: la historia mundana de unos vecinos, sus vidas personales y profesionales, aparece enmarcada por un elemento mítico ya que uno de los protagonistas es un superhéroe. Sus «hazañas», sin embargo, quedan en elipsis, un «dogma» establecido desde buen principio aunque roto puntualmente cuando resulta conveniente para la narración. A menudo las obstrucciones autoimpuestas permiten llegar a resultados creativos más óptimos que la «libertad absoluta», una de las lecciones implícitas en el filme de Jørgen Leth y Lars von Trier Las cinco condiciones (2003) que hemos podido comprobar de primera mano.
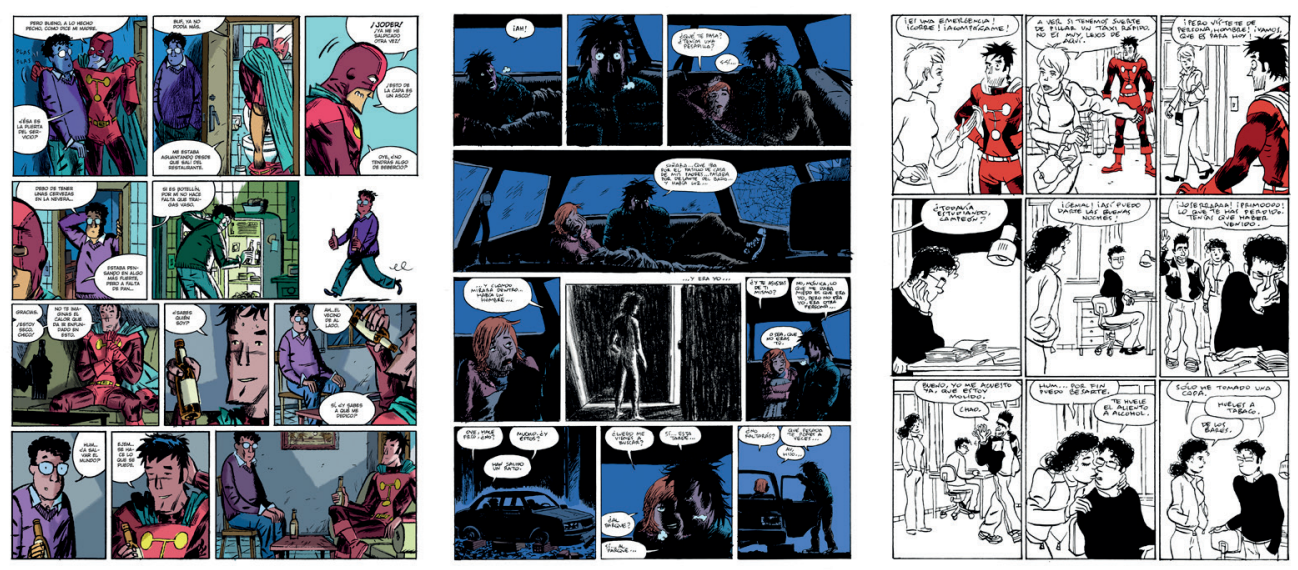

FIG. 1. Páginas de El vecino 1 (2004), El vecino 2 (2007) y El vecino 3 (2009).

El universo superheroico de $E l$ vecino, «en off» respecto a la narración principal, sirve de contrapunto poético a la cotidianidad de un grupo de personajes, treintañeros que se enfrentan a las complicaciones de la vida adulta; de la colisión entre el costumbrismo y la fantasía surgen buena parte de los planteamientos narrativos de la obra, cuya historia ha avanzado a través de constantes cambios de tono, de lo cómico a lo trágico o lo grotesco, a menudo dentro de una misma historia. El vecino investiga asimismo 
los significados ideológicos implícitos en los tópicos de superhéroes a través de una lectura crítica, no exenta de ironía y a la vez de fascinación hacia un género de ficción fundamental en la historia del cómic. Conviene aclarar que $E l$ vecino no pretende ser una parodia de los justicieros enmascarados sino, más bien, un desplazamiento de significado de los mismos: se trata de abordar desde otra perspectiva -oblicua, "periférica»- un género de ficción muy cargado por una larga tradición en el cómic y el cine comercial, a fin de llevar algunos de sus tropos a territorios más cercanos a nuestra realidad. Se pretende así cuestionar los códigos de ficción superheroicos y, desde su atalaya fantástica, sugerir una mirada extrañada sobre nuestras convenciones sociales y rutinas cotidianas.

\section{Historias de vecinos}

El vecino. Historias (2019) es un volumen al margen de la serie principal, una novela gráfica de ciento sesenta páginas a color con historietas breves que amplían el universo narrativo de la obra y, a veces, exploran de manera explícita su trasfondo superheroico. Parte de ellas se publicaron en revistas como El Manglar o NSLM (Nosotros Somos Los Muertos); ${ }^{1}$ cinco historias fueron realizadas ad hoc para el libro. Cada una de ellas plantea juegos narrativos y tonales diferentes, para generar un lenguaje particular distintivo y trascender así las expectativas del lector conforme las lee. Todas las historietas de este volumen experimentan con los recursos formales del cómic, sus convenciones y formatos tradicionales, a menudo desde una franca perspectiva metalingüística y, en algún caso, metaficcional. Otro elemento importante en estas historias, como ocurre a menudo en la serie principal de $E l$ vecino, es el humor y la ironía. La ironía, que permite la doble y a veces triple codificación en el mismo «texto», ha sido un recurso crucial en el arte moderno, en la sátira gráfica del siglo xix (fundamental en la emergencia del cómic moderno) y en la literatura picaresca y satírica de siglos previos. Un recurso que merece ser tomado muy en serio, como argumentó Richard Rorty: la ironía implica el reconocimiento de la contingencia de todas las cosas; ${ }^{2}$ la ironía es antidogmática y manifiesta la duda permanente sobre lo que uno dice y sobre cómo lo dice, sobre nuestro conocimiento e instituciones presentes; la ironía propicia la solidaridad humana. ${ }^{3}$ A continuación examinamos cada una de las historietas siguiendo su orden de aparición en el libro.

\footnotetext{
${ }^{1}$ Agradecemos desde aquí la confianza de los responsables de las revistas El Manglar (Manuel Bartual y Ricardo Esteban) y NSLM (Max, Pere Joan y Álex Fito), donde se publicaron originalmente buena parte de estas historietas. El presente artículo es una reelaboración de una comunicación presentada en el congreso internacional Comics in Dialogue. Conversaciones en torno al cómic (20-23 octubre 2020, Universidad Complutense de Madrid).

${ }^{2}$ Rorty, R. Contingency, Irony, and Solidarity. Cambridge, Cambridge University Press, 1989, p. xv.

${ }^{3}$ Ibid., p. 198.
} 

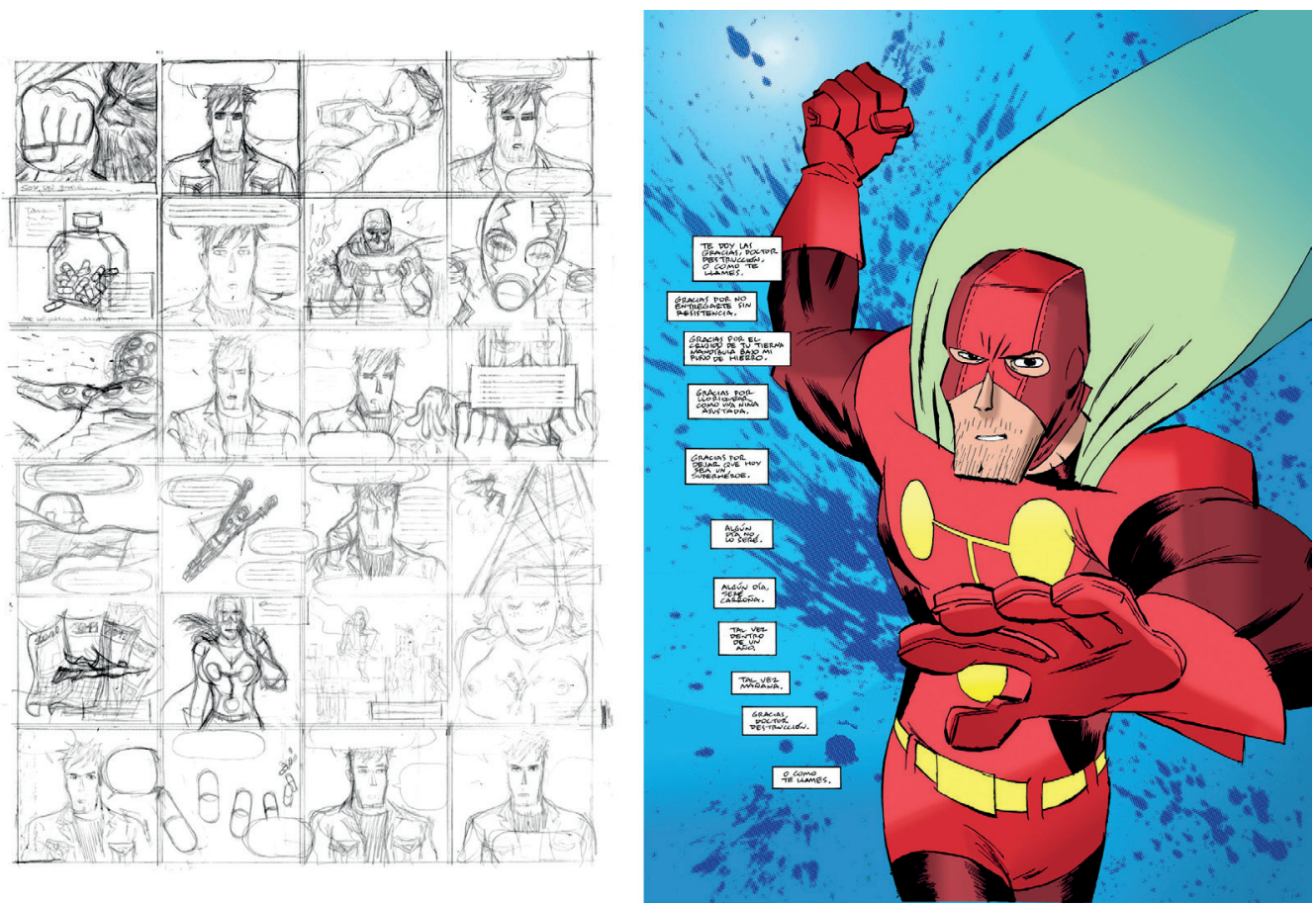

FIG. 2. Las dos páginas de «Soy un superhéroe» (2009): boceto de la primera y acabado de la segunda.

\section{Lo grande, lo pequeño y el (espacio)tiempo comprimido}

En «Soy un superhéroe» (una historieta de dos páginas publicada originalmente en El Manglar n. ${ }^{0}$ 10, julio 2009) el juego formal para exponer la «confesión» de Javier/ Titán interpelando al lector consiste en contraponer el ritmo visual de las veinticuatro miniviñetas de la primera página, una cantidad inusual, con una splash page en la segunda (FIG. 2), lo que supone un cambio narrativo de escala física y mental: por contraste, la viñeta a toda página será percibida aún más grande de lo que es. En el cómic el espacio es tiempo, y cuando leemos una historieta «aprendemos a captar el tiempo espacialmente». ${ }^{4}$ La contraposición de ambas páginas permite asimismo efectos de compresión/descompresión del (espacio)tiempo narrativo. ${ }^{5}$ Fue interesante también colorear con efectos «evidentes» de ordenador, en la estela del extraordinario trabajo de color digital de Lynn Varley para Batman: DK2 (2002). El color digital, introducido en el cómic en la segunda mitad de los años ochenta y desarrollado en

\footnotetext{
${ }^{4}$ McCloud, S. Entender el cómic. El arte invisible. Bilbao, Astiberri, 2005. Traducción de Enrique S. Abulí, p. 100, énfasis original. Román Gubern también indicó que «las estructuras temporales de montaje están indisolublemente ligadas a las estructuras espaciales» en su estudio El lenguaje de los comics. Barcelona, Edicions 62,1972, pp. 170 y ss.

5 Véase McCloud, S. Op. cit., pp. 84-85.
} 
los noventa, se había usado hasta entonces habitualmente para emular texturas y volúmenes ilusionistas. El audaz enfoque de Varley, opuesto, consistió en colorear con ordenador haciendo ostentación de su condición digital: artificial.

\section{Bocadillos de pensamiento y relaciones de contigüidad}
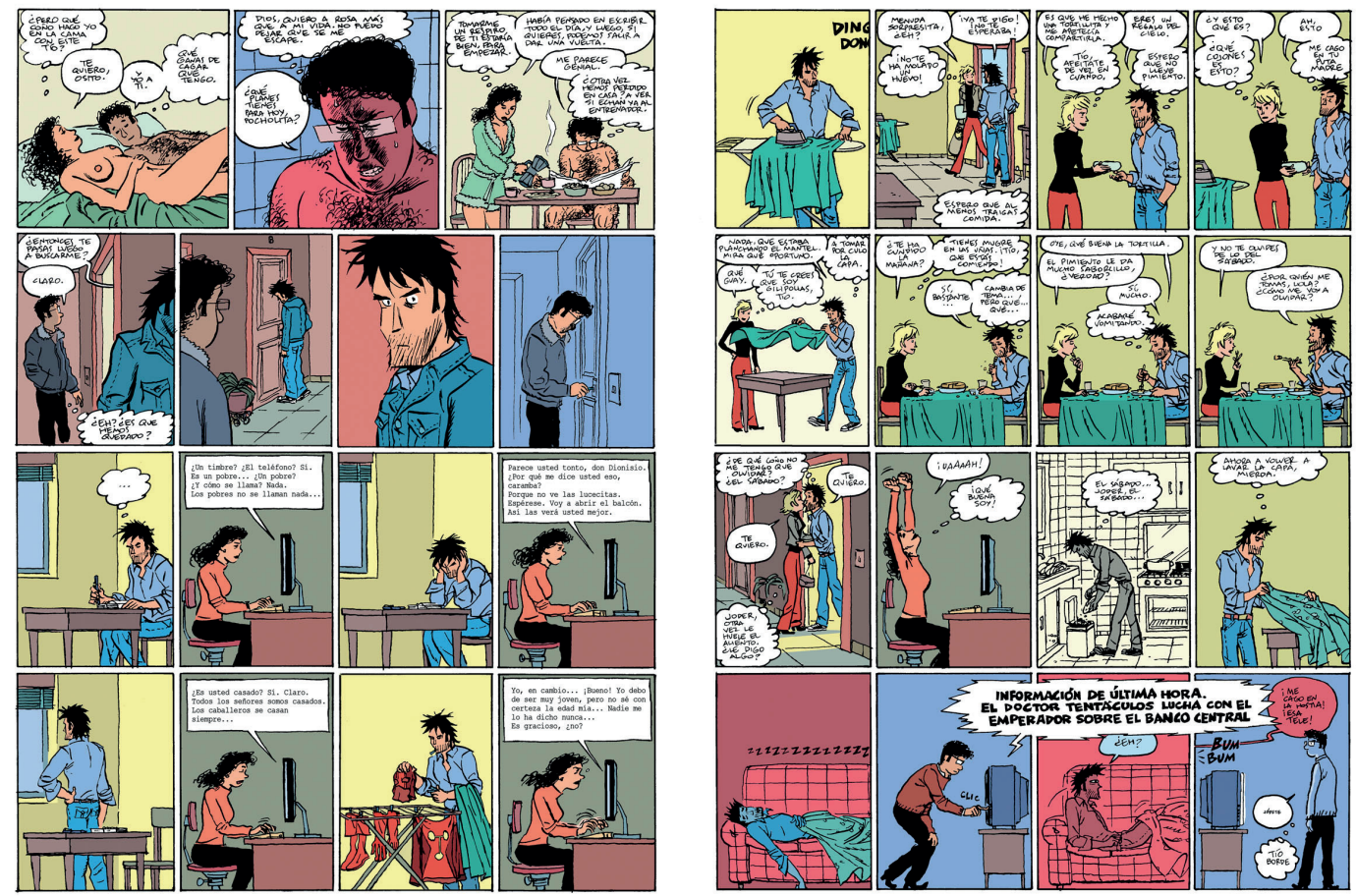

FIG. 3. Las dos primeras páginas de «Lo que me ha pasado hoy» (2007).

En «Lo que me ha pasado hoy» (publicada originalmente en El Manglar n. ${ }^{\circ}$ 3, mayo 2007) se contrasta lo que dicen los personajes con lo que piensan de verdad (FIG. 3). Para ello acudimos a un recurso tradicional del cómic, el globo de pensamiento, en desuso desde finales de los ochenta debido en buena parte a la influencia hegemónica de historietistas como Alan Moore o Frank Miller, que emplearon profusamente el monólogo interior directo en cartucho de texto. Este último sitúa los pensamientos del personaje en un plano más interno y los acercan a la stream of consciousness literaria. Por contraste, el globo de pensamiento tradicional permite mostrar literalmente el discurso mental del personaje en el mismo plano visual en que habla o realiza otras acciones, percibido así de manera simultánea y asociado a él. ${ }^{6}$ Dicho contraste permite desplegar en esta historieta un efecto cómico - lo que dicen los personajes frente a lo

${ }^{6}$ Véase Pérez, P. «El discurso interior en los cómics de Frank Miller», en Ítaca, n. ${ }^{\circ} 1.3$ (2013), pp. $125-128$. 
que piensan de verdad - que plantea implícitamente la oposición entre pensamiento y lenguaje verbalizado, así como el rol que juegan las mentiras (piadosas o maliciosas) en las relaciones personales y sociales. En 2010, Stephen King contaba que, durante su debut como guionista de tebeos en los primeros números de American Vampire, le llamaron los editores de Vertigo/DC para explicarle que, cuando los personajes pensaban, «ya no se usaban» globos de pensamiento como los que él había indicado sino «pequeños cartuchos narrativos»; King se lamentaba de perder ese recurso del cómic. ${ }^{7}$ Con razón.

La gama cromática de esta historieta (FIG. 3) se diseñó para aportar expresividad y separar apartamentos contiguos en secuencias donde los personajes actúan simultáneamente, algo que permite el cómic gracias al panóptico de la página, donde la continuidad narrativa de las imágenes no se produce de una manera estrictamente consecutiva, como en el cine, sino por «relaciones de contigüidad», en términos de Altarriba. ${ }^{8}$ La visión panóptica — característica de las artes de la modernidad, frente a la visión monofocal de la perspectiva renacentista -9 que ofrece la página de cómic permite al lector (re)construir por sí mismo el discurso mediante su lectura. Hablamos de sistemas de unidades icónicas o plásticas que pueden estar informadas simultáneamente por las imágenes vecinas y a veces por imágenes distantes, en una situación de «copresencia»..$^{10}$

\section{La viñeta como camarote de los hermanos Marx}

Como en el caso anterior, en «Mandorla» (publicada originalmente en El Manglar n. ${ }^{\circ}$ 4, julio 2007) se emplea un diseño de retícula uniforme de $4 \mathrm{x} 4$, cuatro tiras de cuatro viñetas, como el compás de una canción pop. O como el diseño base de The Dark Knight Returns (1986), de Frank Miller, Klaus Janson y Lynn Varley. El recurso aquí era sobre todo funcional, porque permitía contar más cosas en el espacio limitado de una revista «tradicional» impresa, como El Manglar, y cómico al mismo tiempo: la acumulación de personajes, acciones y encuadres añadía un ritmo vertiginoso a la comedia de situación habitual en El vecino. Los gags se suceden a esa «velocidad» de 4x4, y llega un momento en que hay más de uno por viñeta; el final, un chiste de situación anticlimático, anticipa nuevas aventuras de Mandorla. El diseño de personajes de este supergrupo-desastre vecinal se inspiró en toda la tradición superheroica, en particular desde la llamada Sil-

\footnotetext{
7 Donnelly, S. «Stephen King on His Comics' Debut», en The Daily Beast, 14 de marzo de 2010. Disponible en https://www.thedailybeast.com/blogs-and-stories/2010-03-14/stephen-king-onhis-comics-debut/2

${ }^{8}$ Véase Altarriba, A. «La historieta, un medio mutante», en Quimera n. 293 (2008), pp. 48-55. Disponible en http://www.antonioaltarriba.com/la-historieta-un-medio-mutante/

9 Ramírez, J. A. El objeto y el aura. (Des)orden visual del arte moderno. Madrid, Akal, 2009, pp. 11-39.

${ }^{10}$ Groensteen, T. The System of Comics. Jackson, University Press of Mississippi, 2007, p. 7.
} 
ver Age (años sesenta) a los justicieros ultraviolentos derivados de El Castigador. ${ }^{11}$ De fondo, también estaban los «superhéroes» en segundo grado ya pasados por el tamiz de la parodia ${ }^{12}$ —el Supergrupo (1979) de Jan y Efepé, en concreto- y alguna persona real que sirvió de modelo. El nombre de nuestro supergrupo, Mandorla, es una broma de Santiago García sobre la historia del arte que alude, en efecto, a la aureola en forma de almendra en la que se insertan personajes sagrados, especialmente en el arte bizantino y románico. Como ya ocurría en «Lo que me ha pasado hoy», el diseño de $4 \times 4$ obligaba a sintetizar el dibujo al máximo para establecer una narración legible (FIG. 4). De hecho, esta historieta acercó el estilo de dibujo de quien escribe estas líneas a la escuela francobelga de línea clara derivada del Tintín de Hergé, y le ayudó a encontrar un estilo más personal. En «Mandorla», buena parte de la gracia estriba en esas viñetas atestadas como el camarote de los hermanos Marx, y justo por eso componerlas no fue tarea fácil. Sin claridad narrativa, nada tendría gracia aquí. O eso intentamos.
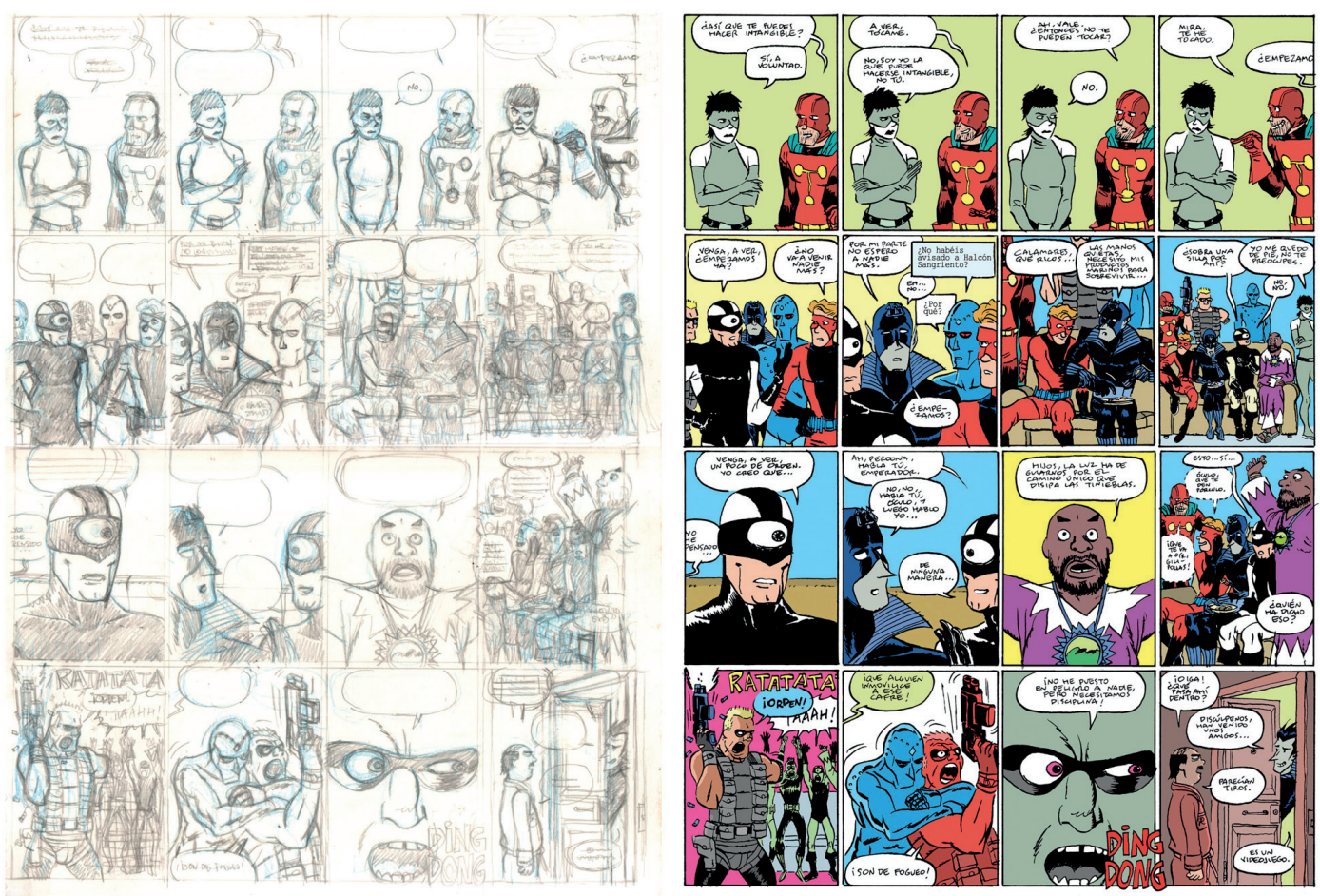

FIG. 4. Proceso para la primera página de «Mandorla» (2007), boceto y acabado.

${ }^{11}$ The Punisher, El Castigador, fue creado en 1974 por Gerry Conway, Ross Andru y John Romita Sr. en The Amazing Spider-Man n. 129 (febrero de 1974), serie Marvel que constituye un referente principal para El vecino. El modelo de El Castigador, que inspiró a otros personajes del comic book a lo largo de los años ochenta, tuvo su apoteosis en los primeros noventa con los superhéroes de la editorial estadounidense Image Comics.

12 Véase Groensteen, T. Parodies. La bande dessinée au second degré. París, Skira Flammarion / Le Musée de la Bande Dessinée, 2010, pp. 7-11. 


\section{Superhéroes «de verdad» y el mito de Lamia}
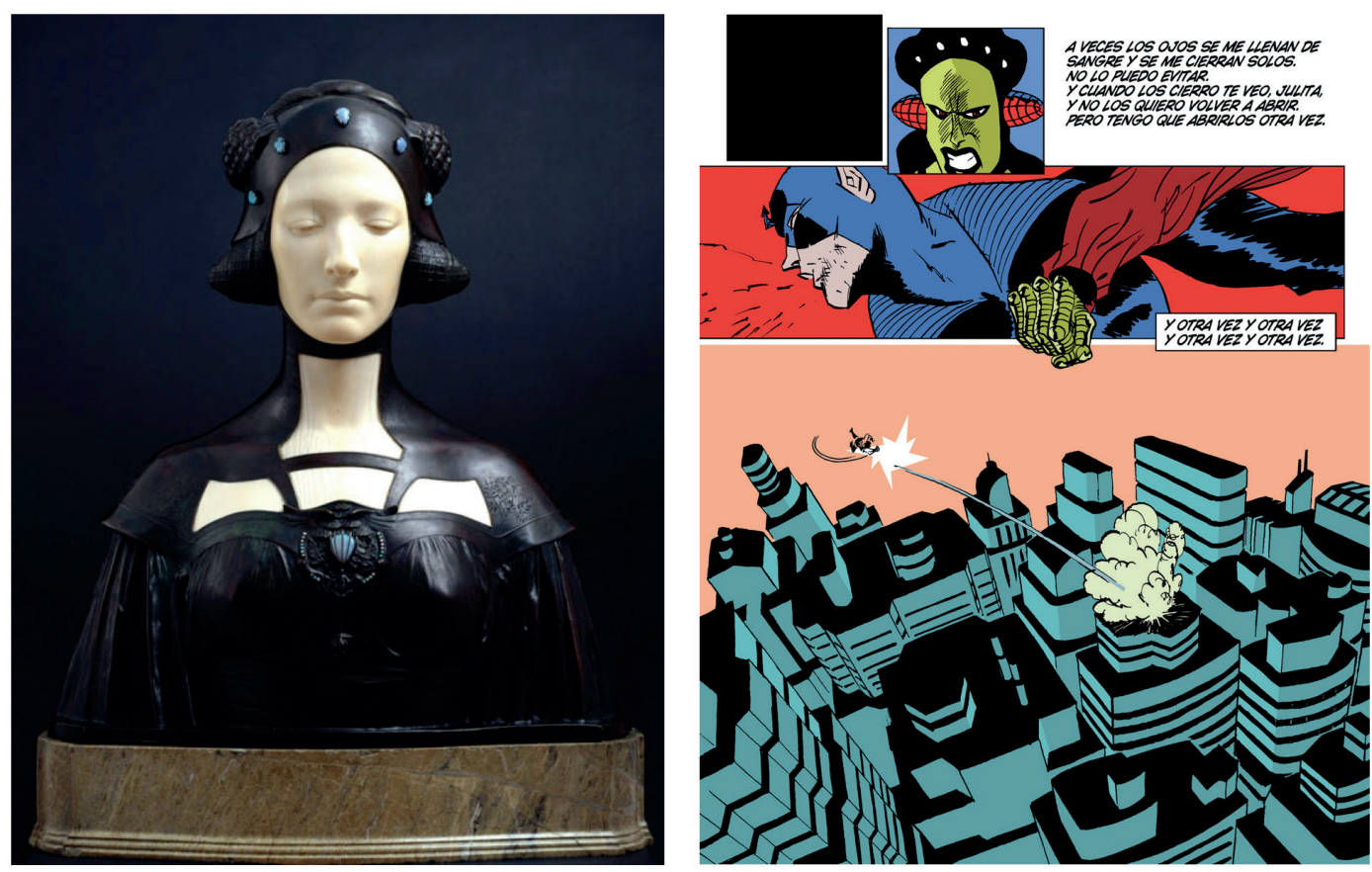

FIG. 5. George Frampton, Lamia (18991900), marfil, bronce, ópalos y vidrio, 610 $\mathrm{mm} \times 553 \mathrm{~mm} \times 254 \mathrm{~mm}$. The Royal Academy of Arts, Londres. Reproducida en la web del museo, Royalacademy.org. Derecha: prueba de color para la primera página de «Todo fue verdad» (2007).

El guion de Santiago García para «Todo fue verdad» (publicada originalmente en El Manglar n. ${ }^{\circ}$ 5, diciembre 2007) planteó nuevos problemas creativos. El tipo de representación previo, la mencionada "caricatura de línea clara», no servía para una historia tan extrema como esta, de superhéroes de verdad que se pelean de verdad. Durante semanas se sucedieron pruebas de estilo, color y entintado, con diferentes plumillas y pinceles; si cambias las herramientas de dibujo, cambias los resultados. El problema principal, no obstante, era cómo representar la escena de violencia con violación final. Tenía que ser algo horrible y sórdido, sin escamotearla mediante siluetas negras, elipsis visuales o trucos similares. La parte más agradecida fue diseñar al personaje de la supervillana Lamia, concebida visualmente a partir del busto simbolista Lamia (1899-1900), de George Frampton, esculpido en bronce y marfil (FIG. 5), inspirado a su vez en el poema homónimo (1819) del romántico John Keats. El personaje mitológico de Lamia puede verse como una encarnación temprana de la belle dame sans merci y la moderna femme fatale, y de ahí la relectura «deconstruida» que pretende plantear nuestra historieta con su brutal desenlace. La legitimidad del poder 
y la violencia es uno de los temas subyacentes en el tratamiento de los superhéroes de El vecino; también intentamos especular con los códigos éticos que tendrían unos superhéroes de un universo más «realista». Cómo se comporta Javier/Titán en otras historias o, en este caso, cómo el superhéroe Emperador se cobra su victoria sobre Lamia. Para dibujar las escenas de acción (FIG. 5, derecha) nos inspiramos en algunos maestros del comic book de superhéroes, con citas expresas en algún caso: estilemas, angulaciones y otros modos de representación de dibujantes como Jack Kirby, Jim Steranko, Frank Miller, John Romita (Sr. y Jr.), Ross Andru o Gil Kane.

\section{Doble monocromo axonométrico}
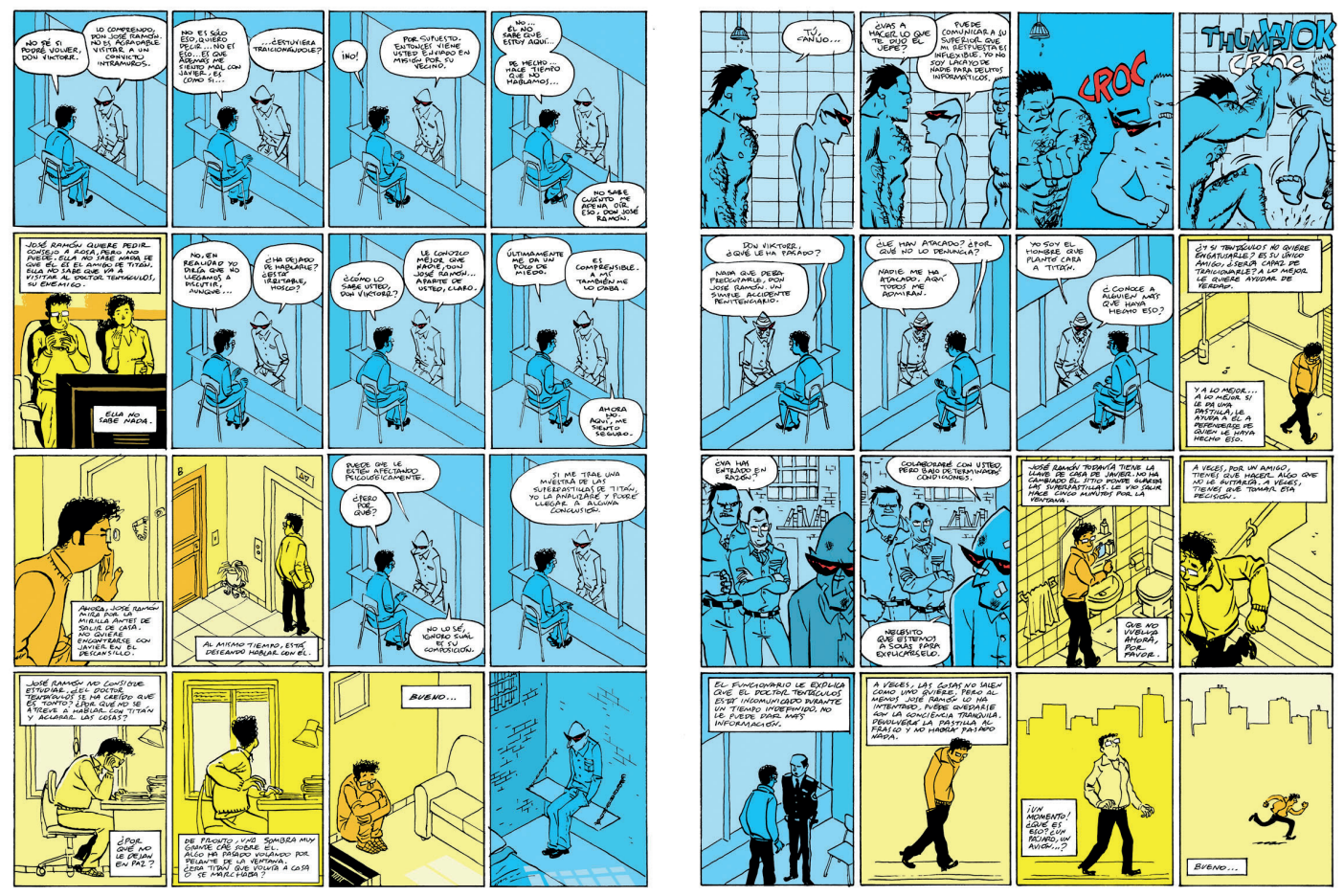

FIG. 6. Las dos páginas enfrentadas de «El visitante» (2008).

$\mathrm{Si}$ «Todo fue verdad» fue la ocasión para comprender la relatividad del concepto de estilo de dibujo, especialmente cuando el tono de la historia pide cambiarlo, para «El visitante» (2008, publicada originalmente en El Manglar n. ${ }^{\circ}$ 6, marzo 2008) sí funcionaba muy bien la caricatura de línea clara de las dos primeras historietas breves de El vecino. En este caso la «obstrucción» creativa de la que partimos era un esquema estricto de color en forma de $\mathrm{V}$, que marcaba todo el diseño de la doble página enfrentada e implicaba un coloreado expresivo; aquí, un doble (seudo)monocromo: azul para la cárcel donde está el Dr. Tentáculos, amarillo para el exterior. Un tipo de color no local ni naturalista, aprendido en viejos tebeos americanos y españoles, 
limitados en su día por la cuatricomía analógica con colores indicados al impresor (y por las prisas para llegar a tiempo a imprenta en publicaciones con periodicidad a veces semanal). La perspectiva axonométrica, invertida en la segunda página (FIG. 6), sirvió para ordenarlo todo visualmente, pero tiene otro efecto psicológico en el lector. Es un tipo de perspectiva casi «anticinematógrafica» que emplea a menudo el novelista gráfico estadounidense Chris Ware, inspirado a su vez en autores del cómic de prensa de las primeras décadas del siglo xx, como Frank King. ${ }^{13}$ El efecto básico en cómic de dicha perspectiva es el extrañamiento con que observamos las cosas; un punto de vista "cósmico», cuasi divino, que convierte a los personajes en animales diminutos que parecen afanarse en tareas «absurdas». Sobre dicha base axonométrica se introdujeron algunas variantes, solo en algunas viñetas, de encuadre y perspectiva. La recuperación del texto de apoyo en tercera persona, otro recurso del cómic tradicional hoy en desuso, es otra apuesta narrativa de esta historia. Es el equivalente al narrador omnisciente literario, aunque en los cómics, y esto es importante, aparece como un elemento textual superpuesto a la imagen. Por tanto, interactúa directamente con esta.

\section{Lo que no es tradición es plagio}

Para «Una nueva oportunidad» (publicada originalmente en El Manglar n. ${ }^{\circ}$ 7, julio 2008) el «estilo» de dibujo ya estaba inventado, solo había que copiarlo. Aquí la obstrucción autoimpuesta consistía en narrar la historieta usando literalmente los modos de las tiras de cómic de prensa diarias y dominicales, un medio/formato hoy prácticamente extinto. Para preparar la historieta, estudiamos comic books y tiras de prensa de Spider-Man, un referente básico en El vecino en general, y en concreto del Spider-Man de John Romita Sr. (FIG. 7). En esta operación apropiacionista surgen gags implícitos meramente de recuperar el formato obsoleto de «tira diaria» de continuidad: el escaso espacio físico disponible, que comprime hasta el absurdo la narración, o las redundancias habituales derivadas de resumir en la primera viñeta lo sucedido en la tira del día anterior por si acaso el lector se la había perdido; algo parecido ocurría a veces con la página dominical respecto a lo narrado durante la semana en la tira diaria. También podríamos ver aquí otro paralelismo respecto a la obsolescencia de medios. La comic-strip de los periódicos — que convirtió al cómic en un medio de masas entre finales del siglo xix y principios del xx- entró en declive hacia los años sesenta del siglo pasado, pero cuando hacemos esta historieta, 2008, la era digital de internet está convirtiendo en irrelevante toda la prensa periódica que se vende en quioscos, y este es otro motivo importante para emular esos formatos anticuados. El Manglar, de hecho, se vendía en algunos quioscos. Otro gag derivado de los modos de representación consistió en copiar casi literalmente alguna viñeta del Spider-Man de Romita Sr.: Lola y Javier bailando, como Mary Jane y Peter Parker, al estilo «guateque» de los se-

${ }^{13}$ Raeburn, D. Chris Ware. New Haven, Yale University Press, 2004, p. 13. 
senta (FIG. 7, izquierda). ${ }^{14}$ La historieta entraba así en el territorio del arte apropiacionista y del «collage expandido, desde el scratch al sampleado, la emergencia del artista como post-productor, un sofisticado re-mixadons. ${ }^{15}$ En consonancia con nuestro objetivo vecinal de replantear clichés de la ficción de género, Javier/Titán combate como superhéroe a una banda de ladrones de joyas que ha asaltado la joyería donde él trabaja para, finalmente, dejar el empleo y llevarse su «finiquito» en forma de botín que él roba en secreto a los ladrones. «Ladrones» como nosotros, o los autores como traductores-traidores.
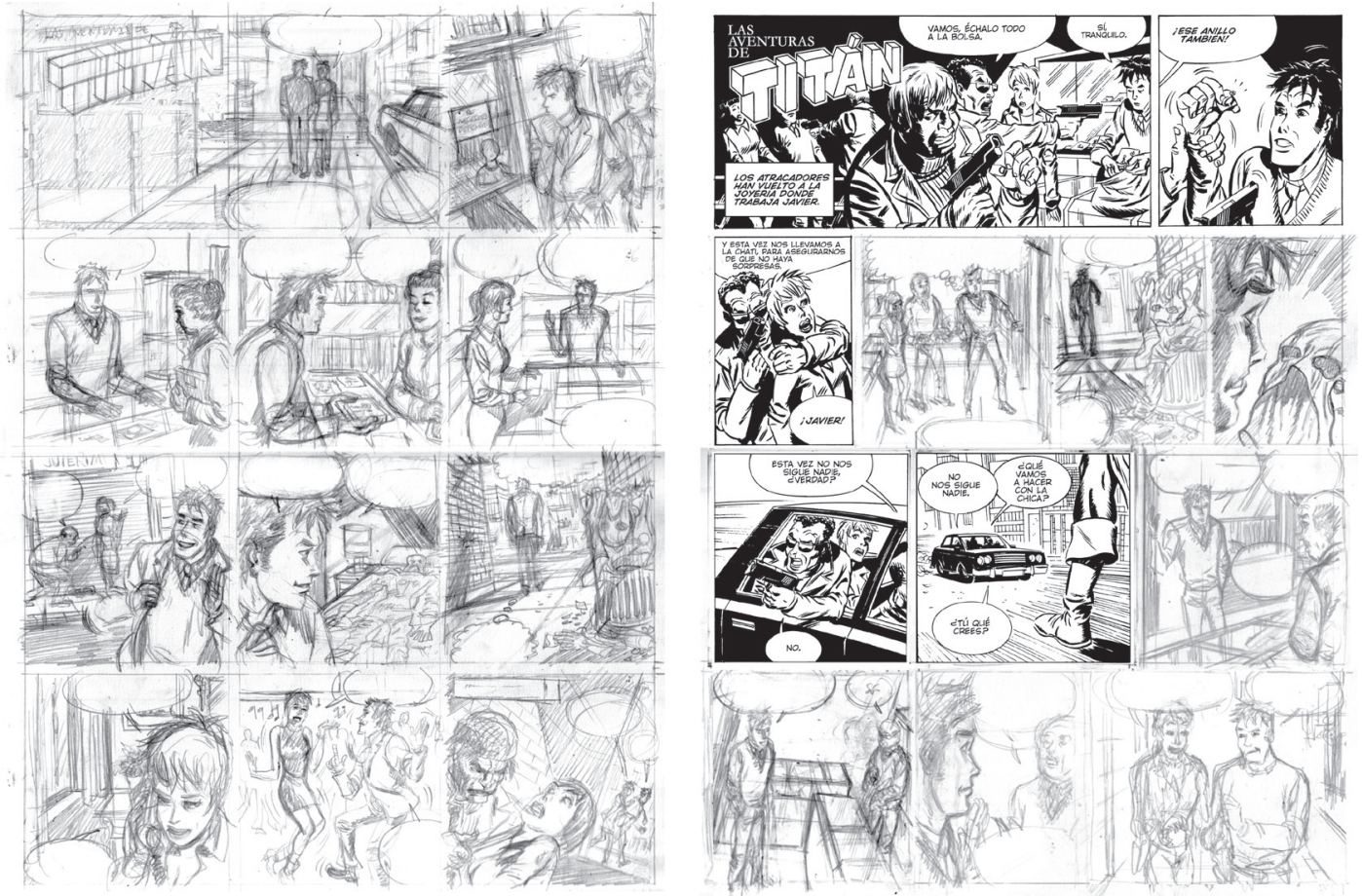

FIG. 7. Dibujos para dos páginas «de prensa dominical» de «Una nueva oportunidad» (2008).

En una historieta tan referencial como esta, que cita escenas muy específicas del comic book de superhéroes, puede constatarse el juego de imitación / variaciones propio de la ficción de género: un tipo de narración que, como observa Coogan, puede ser imitada y reproducida una y otra vez con variaciones, pero manteniendo ciertos elementos constantes puesto que la imitación y la repetición son necesarias para que un género de ficción llegue a existir. ${ }^{16}$ Esa repetición forma parte consustancial de la producción

${ }^{14}$ Véase la viñeta original en The Amazing-Spider-Man n. 47 (1967), reeditada en LEe, S. y Romita, J. The Amazing Spider-Man. Marvel Masterworks Vol. 5. Nueva York, Marvel Comics, 2010, p. 158.

15 Castro Flórez, F. Estética de la crueldad. Madrid, Fórcola, 2019, p. 138. Énfasis original.

16 Coogan, P. «Genre: Reconstructing the Superhero in All-Star Superman», en Smith, M.J.y Duncan, R. (eds.), Critical Approaches to Comics. Theories and Methods. Nueva York, Routledge, 2012, p. 235. 
cultural de masas, porque solo algo que puede ser imitado (repetido con variaciones), que merece ser imitado por su potencial comercial, puede nutrir el sistema de producción. Pensemos en los tópicos y estructuras narrativas de un género, repetidas y familiares - western, negro, superhéroes, etc.-, sobre las cuales en cada nueva narración del género se intentan introducir variaciones inesperadas. Pensemos, por ejemplo, en la enésima ocasión en que en un cómic, una película o una serie audiovisual se vuelve a contar la historia de origen de un superhéroe conocido para actualizarla y, justamente, introducir variaciones en su mito fundacional al gusto de la época, de la empresa productora o de los autores que la recuentan. En nuestra historieta el relato imitado era uno que se volvió recurrente en Spider-Man, el de la renuncia del héroe que le llevaba a colgar las mallas; por supuesto, la serie — la colección abierta e «infinita», sus ventas, la franquicia, etc.- - tenía que continuar y, al final del episodio, superada la crisis de identidad, el superhéroe volvía a disfrazarse para volver a la aventura. En nuestra historieta también lo hace, aunque las variaciones respecto al material imitado no cumplen una función «seria» de producir nuevas historias del género sino, más bien, cómica y de cuestionamiento irónico de los tópicos superheroicos.

Otro recurso imitado aquí fueron los encuadres y angulaciones forzadas en las viñetas (FIG. 7). Como parte de la Marvel de los sesenta, John Romita Sr. tendía a las composiciones de viñeta en diagonal - lo que en cine suele llamarse plano holandés- y usaba de modo muy efectivo la "profundidad de campo" dentro de ella. Esta última técnica la había aprendido de su gran maestro, Milton Caniff, uno de los historietistas de prensa más importantes del siglo xx; de hecho los «ángulos de cámara» de Caniff influyeron en el Citizen Kane (1941) de Orson Welles. ${ }^{17}$ Caniff, de gran influencia en el cómic occidental hasta nuestros días, desarrolló recursos formales para trasladar por equivalencia el modelo de narración invisible del cine de continuidad de Ho1lywood, ${ }^{18}$ acudiendo al plano-contraplano y a la combinación constante de planos medios y generales que permitían una lectura fácil y dinámica. En contraste con los juegos formales artificiosos de marcos visibles de los historietistas de prensa de comienzos del siglo xx, anteriores a la influencia masiva del cine, en Caniff la viñeta es

${ }^{17}$ Harvey, R. C. Meanwhile... A Biography of Milton Caniff. Seattle, Fantagraphics, 2007, p. 335.

${ }^{18}$ El modelo de continuidad del cine de Hollywood se «fundamentaba en la perfecta adecuación a la narratividad y su finalidad era la transparencia, es decir, que la técnica quedara oculta detrás de la representación que se ponía en pie. Por decirlo de otro modo, que el espectador no se apercibiera del trabajo de montaje que está detrás de la obra en sí. Todo actuaría en busca de la entrada del espectador en el universo de ficción de la manera menos problemática posible». BenEt, V.J. La cultura del cine. Barcelona, Paidós, 2004, p. 82. Al mismo modelo de cine narrativo se refirió Laura Mulvey en su conocido ensayo «Visual Pleasure and Narrative Cinema» (1975), donde afirmaba que el cine dominante en Hollywood había tendido a reproducir cuidadosamente las condiciones naturales de la percepción humana. Las técnicas de filmación (profundidad de campo, movimientos de cámara determinados por la acción del protagonista, montaje invisible como exigencia de realismo) tendían a difuminar los límites del espacio de la pantalla. Vid. Mulvey, L. «Visual Pleasure and Narrative Cinema», en Braudy, L. y Cohen, M. (eds.). Film Theory and Criticism: Introductory Readings. Nueva York, Oxford University Press, 1999, pp. 838-844. 
invisible, «una ventana impermeable que define los límites del cuadro dibujado, y lo que sucede en ella, como lo que sucede en la pantalla, es una simulación de la realidad que centra exclusivamente toda nuestra atención». ${ }^{19}$
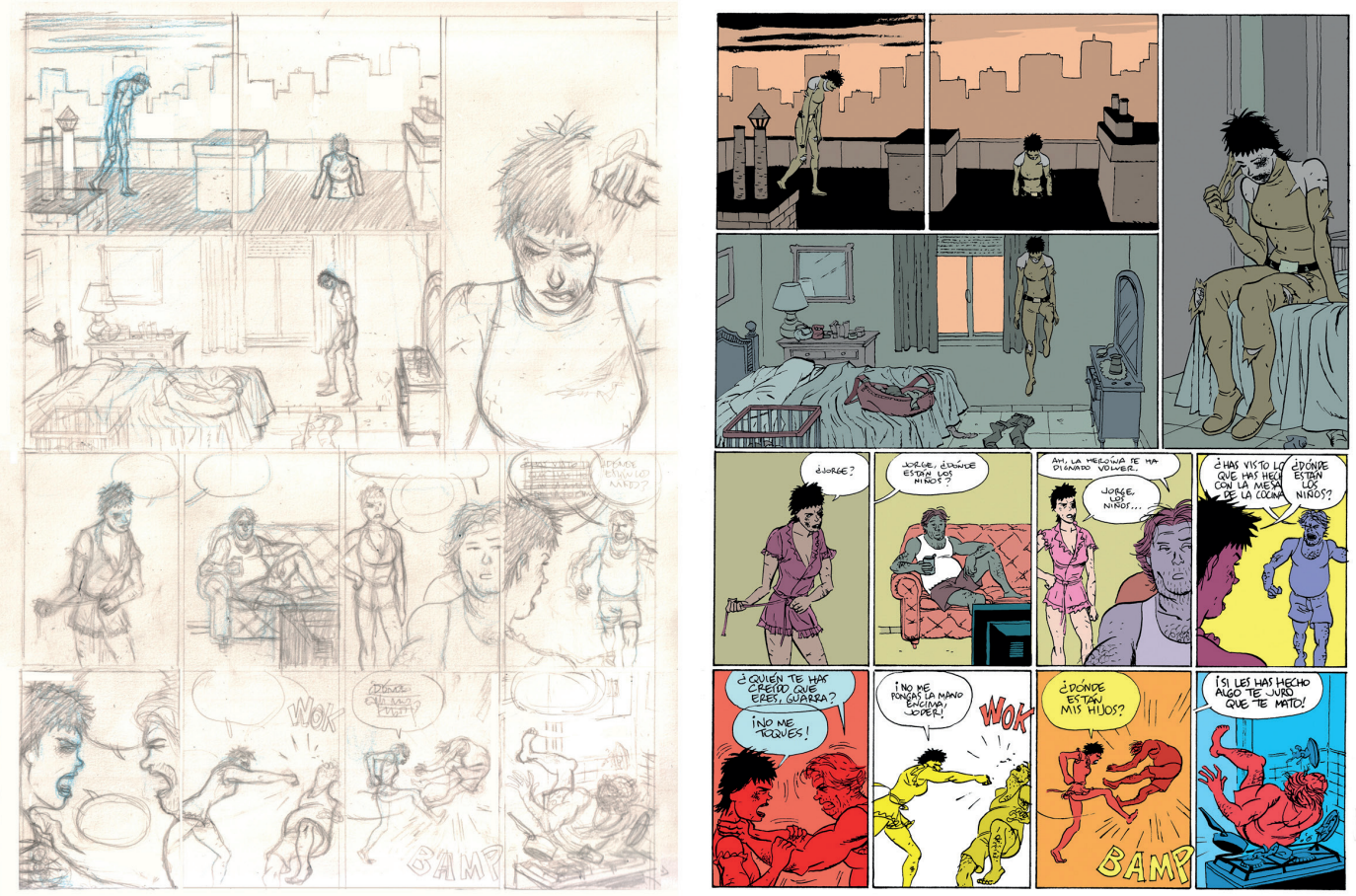

FIG. 8. Proceso para la décima página de «Táctila» (2008), boceto y acabado.

El Spider-Man de Romita Sr. participa de esa concepción «cinematográfica» del cómic, añadiendo los encuadres forzados, típicos en la Marvel de los sesenta. Al copiar sus modos visuales también participamos de ese modelo, en contraste con el resto de El vecino, donde en general nos alejamos del cómic «cinematográfico». Podemos comprobarlo también en la FIG. 8, con las tres primeras viñetas vinculadas artificiosamente por el marco arquitectónico, lo que implica un diseño muy artificioso - en la tradición de Winsor McCay o Frank King-, que rompe la ilusión de simulación con la viñeta como marco o cámara «invisible», que se torna manifiestamente visible. En «Una nueva oportunidad», en cambio, emulamos un tipo de representación muy adecuado para el género de superhéroes, especialmente en una época, años sesenta y setenta, en que la acción audiovisual aún no podía rivalizar con los comic books debido a la precariedad de los efectos especiales en cine y televisión; un tipo de representación que también practicaron, a su estilo, dibujantes como John Buscema, Gil Kane o Ross Andru. Con semejantes angulaciones y contrapicados, hasta las escenas cotidianas más vulgares parecían una «aventura electrizante». Justo de eso se trataba aquí.

${ }^{19}$ García, S. La novela gráfica. Bilbao, Astiberri, 2010, pp. 98-99. 
Por supuesto, el recurso es resignificado de nuevo en la medida en que lo usamos fuera de su contexto histórico y lo trasladamos al universo «vecinal»; el resultado vuelve a a ser implícitamente irónico, y más considerando el contraste formal con el resto de El vecino. Pero, como diría Eco, no podemos volver a visitar el pasado que conocemos - por mucho que lo amemos- con falsa inocencia. La única forma de revisitarlo es «con ironía, sin ingenuidad». ${ }^{20}$

\section{Registro politonal}

En «Táctila» (publicada originalmente en El Manglar n. ${ }^{\circ}$ 8, noviembre 2008) abordamos el tema principal de la historia - la vida de un matrimonio en decadencia, con una madre agobiada por el trabajo fuera y dentro del hogar y un marido alcohólico e indolente- mediante el habitual registro politonal de El vecino, con contrastes entre lo cómico, lo dramático, lo grotesco, etc. Ese tono variable pedía en ocasiones un registro de caricatura más realista. En la FIG. 8 (izquierda) hay variantes de la versión final, descartadas por cuestiones de narración, perspectiva y continuidad / contigüidad de las viñetas en el diseño de página. En la página acabada (FIG. 8, derecha) puede apreciarse el contraste de un coloreado hasta cierto punto naturalista (primeras siete viñetas) con una gama cromática expresiva y antinaturalista, muy de tebeo tradicional (últimas cinco viñetas).

\section{Desbordamiento del inconsciente}

«En el pozo» (publicada originalmente en El Manglar n. ${ }^{\circ}$ 9, marzo 2009) es una historia bastante críptica, ya desde el guion, pero no quisimos revelar más sobre el significado de la narración para que esta funcionase a un nivel visual y sensorial. Ciertamente, el lector no puede conocer los «detalles» de fondo (quién es el minero atrapado ni por qué está ahí Rafael, el androide de Mandorla), pero ese misterio resulta productivo, artísticamente hablando. Y la página final (FIG. 9), un «nacimiento» desde una mina convertida en tumba para los mineros, es algo que cualquiera puede entender. En palabras de Santamaría, «no es necesario decodificar, ni siquiera leer entre líneas - ni conocer las causas-, sino permitir que el lenguaje explote. $\mathrm{O}$ dicho en otros términos, desbordar el propio concepto cerrado y puro de inconsciente». ${ }^{21}$

Hay otro recurso, de diseño, para añadir atmósfera y textura: el gutter o calle entre viñetas es negro en todas las páginas, «a sangre» por todos los laterales, y, salvo al final, no se usan marcos rectilíneos (descartados respecto al boceto inicial, véase FIG. 9).

\footnotetext{
${ }^{20}$ Eco, U. Apostillas a El nombre de la rosa. Barcelona, Lumen, 1985, p. 29. Traducción de Ricardo Pochtar.

${ }^{21}$ Santamaría, A. Narración o barbarie. Vitoria-Gasteiz, Sans Soleil, 2017, p. 42.
} 
Dentro del «pozo», la linterna del minero y los ojos de Rafael son las únicas fuentes de luz, y sus límites en claroscuro definen el contorno variable de las viñetas. Así tienden a confundirse unas con otras en el lienzo tenebroso de la página, tanto como el efecto de «clausura» ${ }^{22}$ para «rellenar los huecos» de las elipsis entre viñetas por parte del lector.

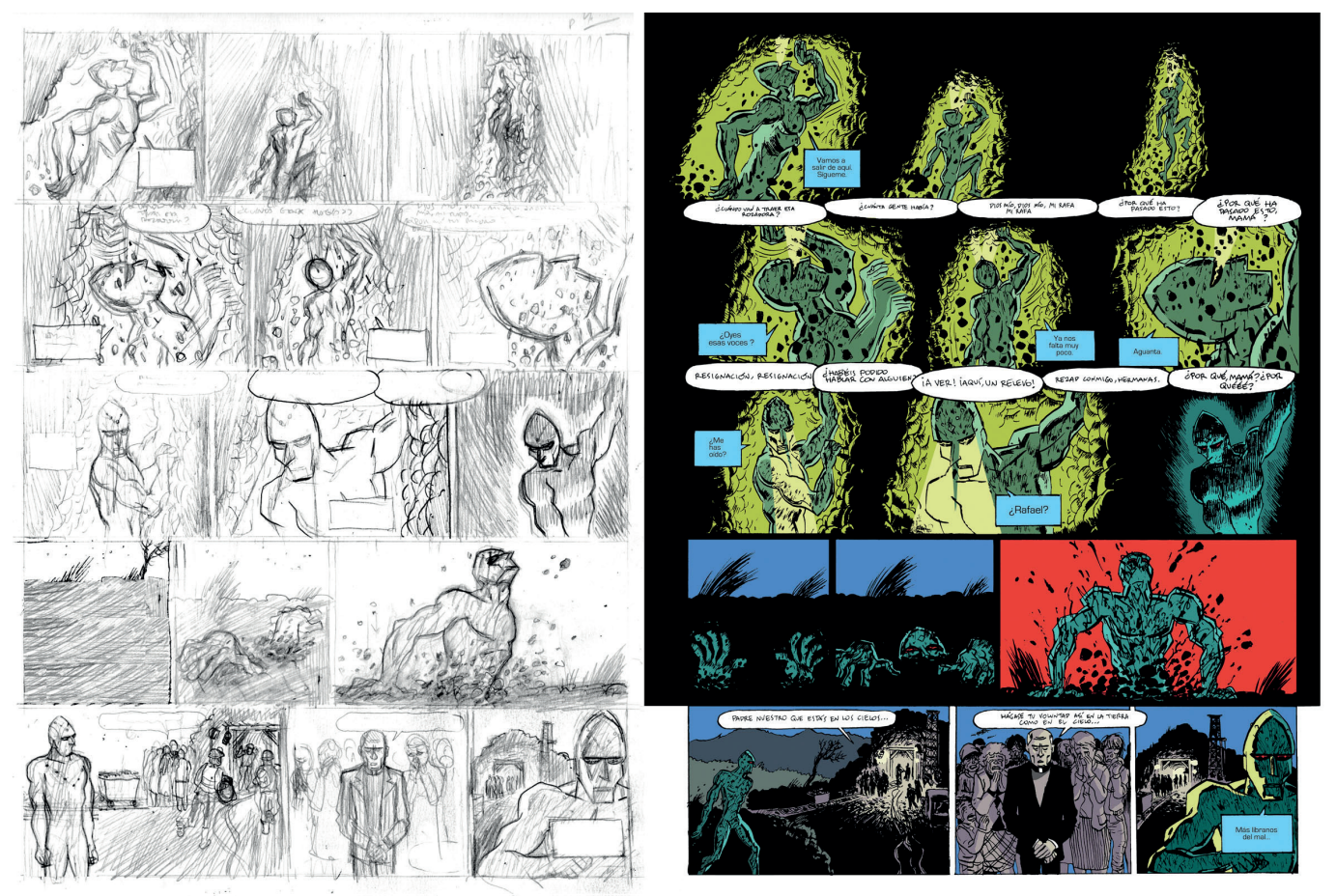

FIG. 9. Proceso para la última página de «En el pozo» (2009), boceto y acabado.

\section{Civiles enmascarados en perspectiva axonométrica}

«Mi padre fue un gran superhéroe» (publicada originalmente en El Manglar n. ${ }^{\circ} 11$, noviembre 2009) era un guion de duelo de Santiago García, una elegía al padre en clave de superhéroes que van disfrazados también en su vida civil. Esta historieta es, en cierto modo, el «Death-Ray» (2004, Daniel Clowes) del universo vecinal, por sus alusiones emocionales alegorizadas mediante códigos superheroicos. Hay dos escenas que queremos destacar aquí. Por un lado, la cena navideña, de nuevo bajo la influencia «axonométrica» de Chris Ware (FIG. 10, izquierda), lo que supone combinar dos tradiciones formales del cómic, ambas norteamericanas pero en cierto modo antagónicas: la tira de prensa para todos los públicos, elegante y artística, de la que bebe mayormente Ware, frente al comic book de superhéroes, bruto e infantil. A ello se añade la tradición europea de línea clara en el dibujo y el color, con tonos cromáticos

${ }^{22}$ Véase McCloud, S. Op. cit., pp. 63-67. 
naturalistas para los fondos y tonos más brillantes en los personajes para destacarlos. Nótese que en la primera escena de esa misma página, de acción superheroica (primeras cuatro viñetas), el estilo de coloreado es el «opuesto»: expresivo, antinaturalista y de tonos saturados, propios de una escena de acción en un comic book de superhéroes; por ejemplo, uno coloreado por Marie Severin para la Marvel clásica. Por otro lado, una escena que contrasta en las mismas viñetas la memoria sentimental íntima del personaje de Guerrillero — en diálogo extrañado, interpelando al lector y rompiendo la «cuarta pared»- con el escenario de acción violenta (FIG. 10, derecha, últimas tres viñetas). El recurso contrapone el texto a la imagen: el diálogo íntimo, que por sí mismo sugiere imágenes mentales al lector, está en un plano conceptual diferente evoca el pasado del personaje - al del escenario ultraviolento que muestra el dibujo, coloreado en monocromo. El contraste podría verse también como un cuestionamiento del presente continuo como tiempo típico del cómic tradicional de superhéroes y aventuras; un tiempo en el que no parecía existir el pasado, la historia, la memoria.
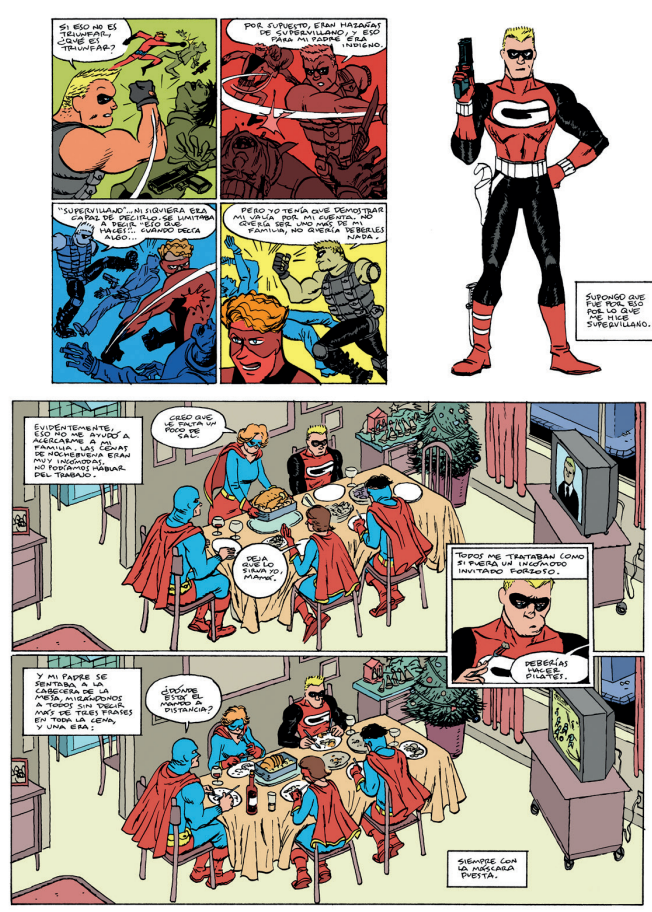
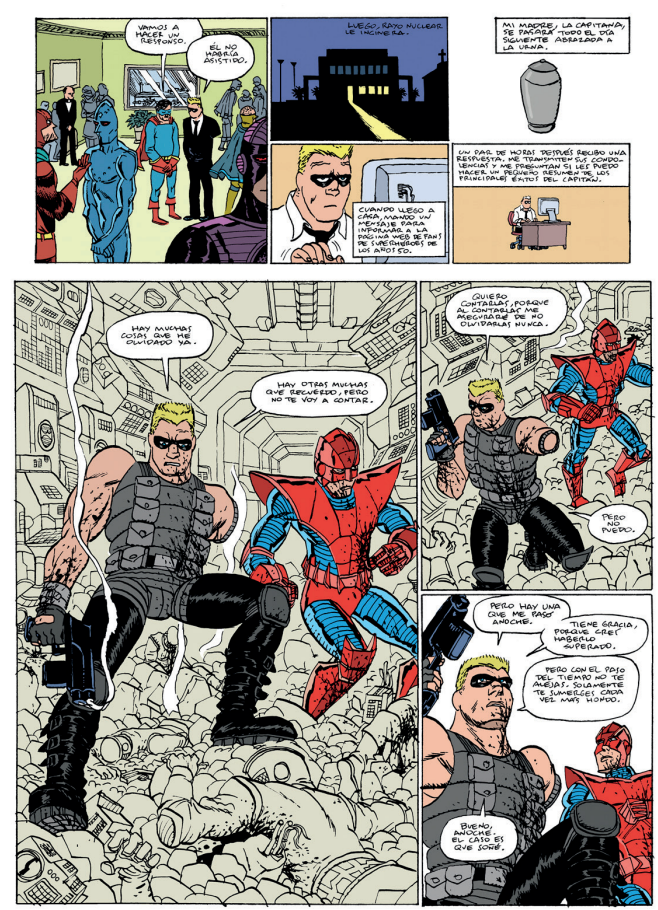

FIG. 10. Dos páginas no consecutivas de «Mi padre fue un gran superhéroe» (2009).

\section{Premios en blanco}

«Los premios» (publicada originalmente en El Manglar n. ${ }^{\circ}$ 12, junio 2010) es una comedia de situación, la base original de $E l$ vecino, con astracanada final. También es nuestra versión superheroica de los premios del Salón Internacional del Cómic de 
Barcelona, que permitió algunos «cameos» dibujados. Así, entre el público aparecen los 3 Titanes, protagonistas de la inspiradora novela gráfica de Juaco Vizuete El experimento (2009), y también, un poco como roman à clef, algún conocido crítico del cómic español y otros visitantes asiduos del Salón de Barcelona; como en otras historias de este libro, la metaficción se cuela en el tejido del universo vecinal. En este caso (FIG. 11) destacamos el empleo de la rotulación como elemento de dibujo (exactamente lo que es, de ahí que rotulemos manualmente, como todo lo demás que hay dibujado en la página) y el uso del blanco como «color» expresivo, un recurso inspirado en viejos tebeos francobelgas y españoles, cuando el colorista o separador dejaba de colorear algunos elementos en las viñetas. Lo que entonces era una estrategia para el ahorro, de tiempo y dinero en la impresión, ahora resulta un recurso cromático muy efectivo.
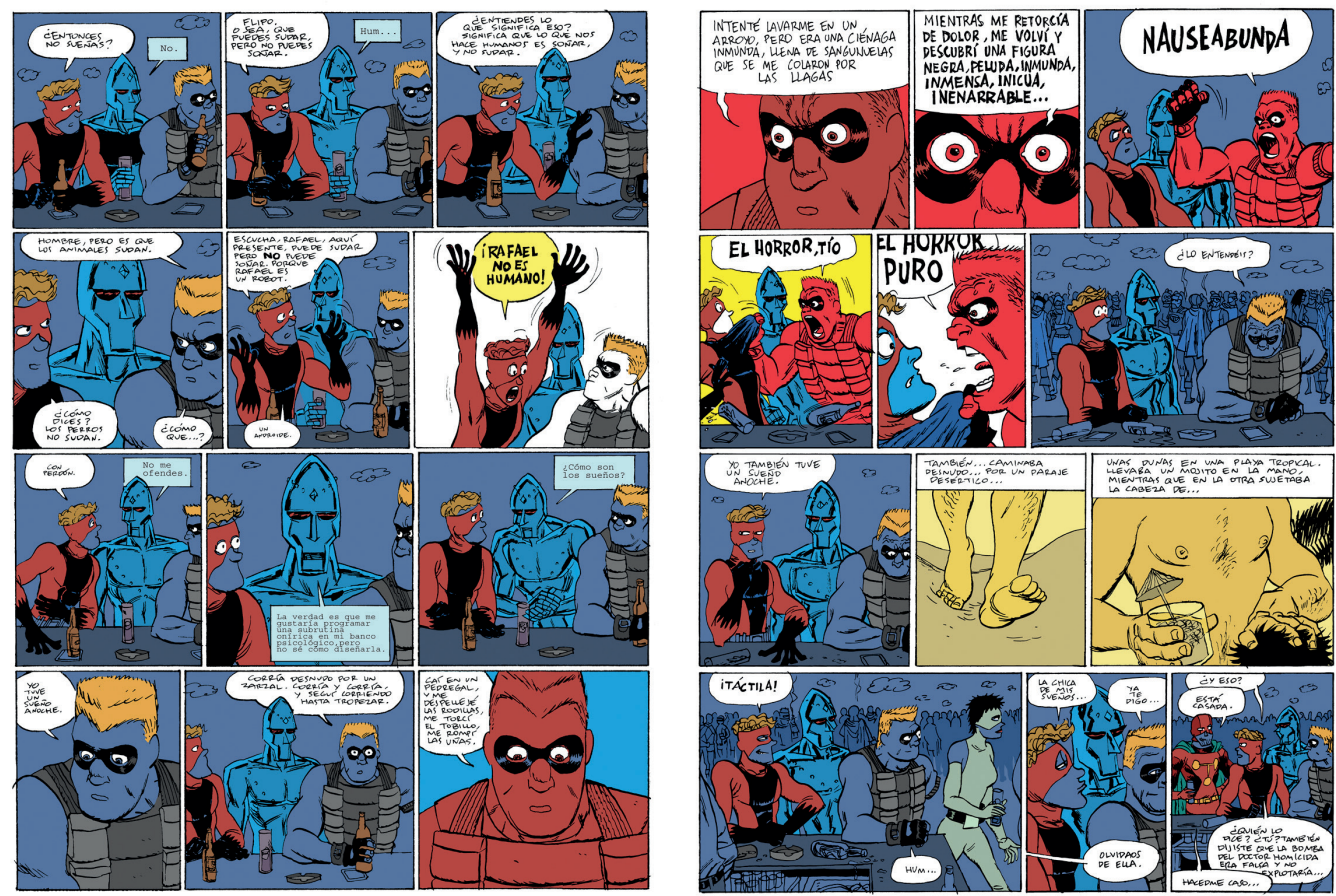

FIG. 11. Dos páginas consecutivas de «Los premios» (2010).

\section{«Des-reconocimiento" y "co-producción» de ficciones: El vecino «weird»}

«Ich Liebe Dich // Ich Dich Auch Nicht» era una historia escrita en 2010 y pensada para una antología de la editorial de cómic de vanguardia Apa-Apa que no vio la luz finalmente. La recuperamos, dibujada en 2019, para aportar otro registro estético, más experimental, a El vecino. Historias. Aquí hay un recurso principal de extrañamiento: los diálogos en lenguaje «alienígena» (alemán en realidad, pero el lector que no conoce ese idioma tarda un poco en reconocerlo) y los supuestos «subtítulos» españoles 
en cartuchos de texto, absurdistas como de vanguardias literarias. La combinación de ambos planos de texto, diálogos y cartuchos, deviene en una aparente incoherencia superpuesta a las imágenes, que por contraste son claras y establecen una narración de «hechos coherentes». También experimentamos con recursos visuales como el doble monocromo rojo/azul y dos tipos de acabado: tinta limpia, sintética, para dibujar el «Titán-rubio»; lápices sucios, como de cómic underground, para el «Titán-moreno». Las dos tiras verticales (FIG.12) fueron dibujadas por separado para montarlas luego en el ordenador, en un proceso con algo de «laboratorio» porque no podía calcularse exactamente el resultado final. La razón de la elección cromática rojo/azul, por cierto, es que se trata de los colores básicos del uniforme de superhéroes clásicos: Superman, Wonder Woman, Capitán América, Spider-Man, Thor.
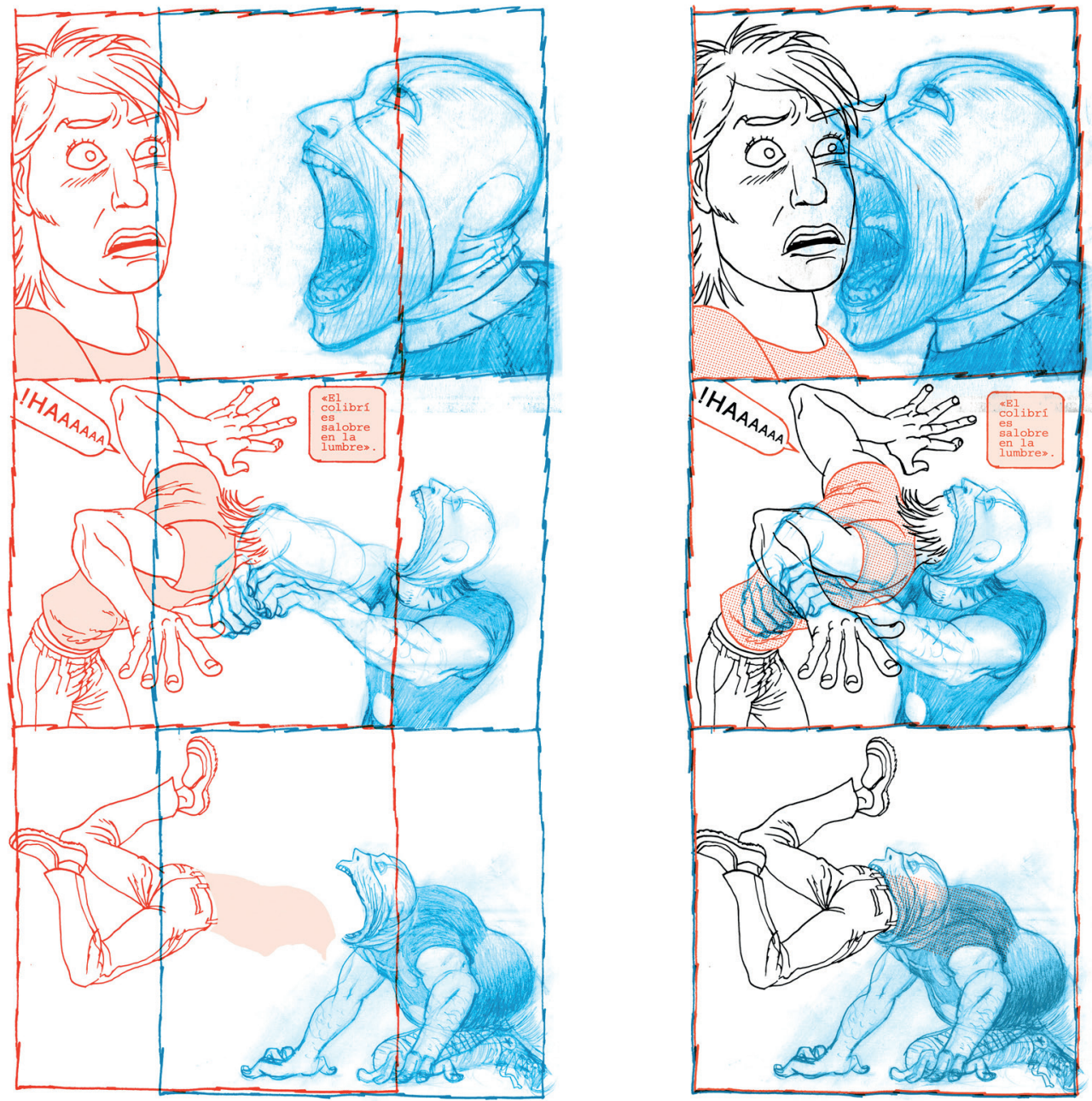

FIG. 12. Proceso para la quinta página de «Ich Liebe Dich // Ich Dich Auch Nicht» (2019): superponiendo las dos tiras verticales azul/roja (izquierda) y resultado final para imprenta (derecha). 
«Ich Liebe Dich // Ich Dich Auch Nicht» se sustenta sobre todo como experiencia visual y sensorial. Aunque como relato resulta extraño, incluso incomprensible para el lector, la historia tiene mucho más sentido del que parece... como se revelará en El vecino 5. Se trata de un tipo de proceso creativo habitual en cineastas como David Lynch, cuyas historias no son verdaderas alegorías sino narraciones «literales» $\mathrm{y}$ «lineales», solo que desmontadas - incluso eliminando escenas del guion o secuencias ya rodadaspara generar «misterio». ${ }^{23}$ Puelles Romero observa, a partir de la fase del «des-reconocimiento» ${ }^{24}$ en la experiencia estética que definió Rubert de Ventós, lo siguiente:

Efectivamente, no hay experiencia estética si no hay dificultad para la comprensión, la cual no se las verá con lo reconocible sino con lo que trasciende lo ya conocido. Para que se produzca la experiencia de la comprensión de la ficción es preciso ser tomado por ella, que nos sobrepase y nos perturbe. Solo así se pone en juego - al fin placentero- nuestra subjetividad íntima. ${ }^{25}$

En esta historieta se plantea además un tipo de operación que elude la jerarquía habitual en la relación narrador-espectador (el narrador relata «desde arriba», el espectador descifra racionalmente el relato «desde abajo») y que define Santamaría en estos términos:

En lugar de decodificar símbolos, se trataría, efectivamente, de co-producir ficciones (y en esta co-producción hay también cuestiones políticas). Este proceso de intervención viene prefigurado, a su vez, no por la construcción de un sentido, ni siquiera por la organización de un discurso que interprete ciertos símbolos, sino bajo la idea de que es el propio inconsciente capaz él sólo de producir un sentido. ${ }^{26}$

En esta coproducción de ficciones hay algo que recuerda al proceso de «lectura creativa» que tenía lugar cuando, hace décadas, el lector infantil seguía colecciones de tebeos tradicionales de manera incompleta y desordenada debido a la mala distribución editorial. Este fenómeno obligaba al lector, para dotar de sentido a una narración seriada,

23 Para la película Lost Highway (1997), véase Rodley, C. (ed.). David Lynch por David Lynch. Barcelona, Alba, 1998, pp. 360-372. Traducción de Manu Berástegui y Javier Lago. O bien, para el argumento de Mulholland Drive (2001), barajando «recuerdos, fantasías, deseos y sueños del futuro mientras nos movemos a través de lo que realmente ocurre a nuestro alrededor en el transcurso de un día». Lynch, D. y McKenna, K. Espacio para soñar. Barcelona, Reservoir Books, 2018, p. 454. Traducción de Aurora Echevarría y Luis Murillo.

${ }^{24}$ A las fases de des-concierto y re-conocimiento le seguiría la fase culminante de des-reconocimiento, en la que la obra transciende nuestras expectativas, y rebasa o incluso embota nuestra capacidad de experimentarla. Véase Rubert de Ventós, X. El cortesano y su fantasma. Barcelona, Destino, 1991, pp. 237-244.

25 Puelles Romero, L. Mirar al que mira. Teoría estética y sujeto espectador. Madrid, Abada, 2011, p. 182.

${ }^{26}$ Santamaría, A. Op. cit., p. 42. 
a imaginar episodios enteros, anteriores y posteriores, que en muchos casos nunca llegaría a leer por el mismo problema de distribución. En pocas palabras, llegaban a coexistir una narración canónica, la que realmente se producía en las series de tebeos, con un número indeterminado de narraciones imaginarias o alternativas, coproducidas por los lectores. Pero «Ich Liebe Dich // Ich Dich Auch Nicht» supone también la irrupción de lo raro en el universo de El vecino. Más allá de lo unheimlich freudiano, para Fisher lo weird o raro implica la sensación de algo erróneo: una entidad u objeto tan extraño que nos hace sentir que no debería existir ahi, ${ }^{27}$ cuestionando las categorías hasta entonces válidas para dar sentido al mundo, que devienen así obsoletas. Lo raro nos permite ver el interior desde la perspectiva exterior, con «un goce que, por ser una mezcla de placer y dolor, tiene relación con lo que Lacan llama jouissance». ${ }^{28}$

\section{Desplazando el significado de los símbolos del poder}

«Tirana» (2019) es otra de las historietas realizadas para El vecino. Historias, previamente inédita, que nos ha permitido retomar a un personaje femenino destacado, Paloma/Táctila (aparecida en «Mandorla» y protagonista en «Táctila») y desarrollar a otro secundario, Tirana y su látigo mágico. Tirana tiene ahora algo de Mademoiselle Bourgeoise Noire, persona creada en los primeros ochenta para performances no anunciadas como tales por la artista estadounidense Lorraine O'Grady, ${ }^{29}$ una de las fundadoras de Guerrilla Girls (FIG. 13). Como historia, «Tirana» es, en buena parte, una respuesta satírica a la reacción ultraconservadora reciente, que aborda temas como el machismo o las nuevas y antiguas subjetividades, femeninas y masculinas. Hay ironía y comedia, drama y melodrama, en el registro politonal habitual de El vecino. Por eso el dibujo navega desde una caricatura más realista a un registro más cartoony o satírico, según la escena. Como en la página de la FIG. 14, con un político inspirado en cierto líder de partido real; los supervillanos que le apoyan están dibujados con un estilo satírico a lo Frank Miller y Lynn Varley. Como observa el artista visual Chema Cobo: «¿A quién le interesa el símbolo? Al poder. Y le interesan los símbolos cerrados porque estos son los que limitan la percepción y, por lo tanto, el conocimiento». ${ }^{30} \mathrm{De}$

${ }^{27}$ Fisher, M. Lo raro y lo espeluznante. Barcelona, Alpha Decay, 2018, p. 19. Traducción de Núria Molines.

${ }^{28}$ Ibid., p. 15.

29 «Ataviada con un extraño vestido blanco hecho con 180 pares de guantes blancos que acompañaba con un látigo de nueve colas elaborado con un cabo marinero y adornado con crisantemos blancos, se colaba, con el aspecto de una debutante, reina de la belleza o diva, en las fiestas e inauguraciones de arte para manifestarse contra el "apartheid racial" del establishment artístico de Nueva York». Sichel, B. y Krulik, B. «Lorraine O'Grady», en Sichel, B. y Krulik, B (dir.). Lorraine O'Grady. Aproximación inicial / Initial Recognition. Sevilla, Consejería de Cultura Junta de Andalucía / Centro Andaluz de Arte Contemporáneo, 2016, pp. 10-11.

30 Сово, C. у Umbría, A. «Last Supper/Late Nerws. Conversación entre Chema Cobo y Ana Umbría», en Сово, С. O ut of Frame. Málaga, CAC Málaga, 2009, p. 35. 
ahí el reto creativo para desplazar el significado de determinados símbolos. En «Tirana», aquello que en nuestra realidad actual se presenta como políticas «serias» por determinados políticos populistas es literalizado en clave cómico-satírica.

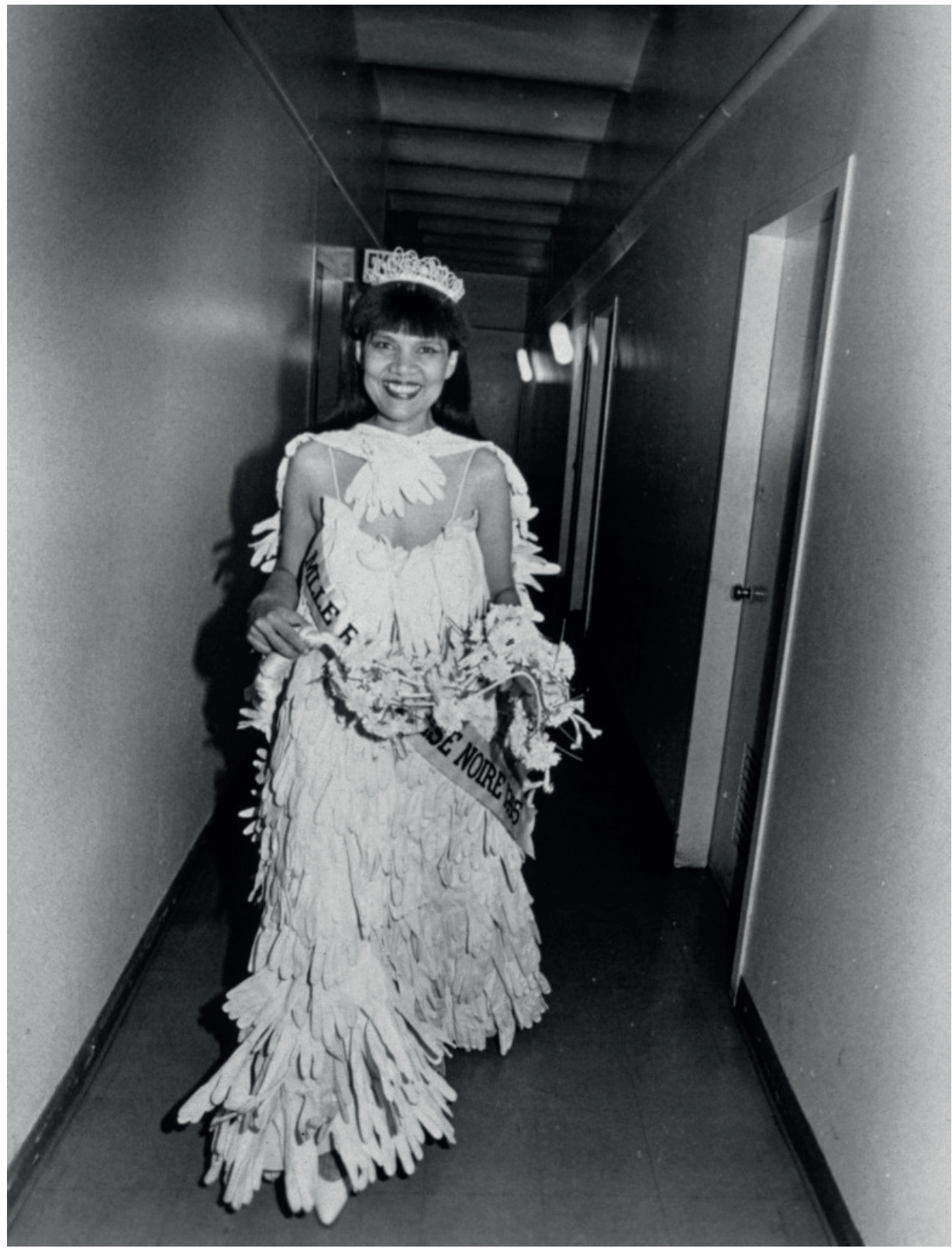

FIG. 13. Lorraine O'Grady, Untitled (Mlle Bourgeoise Noire Leaves the Safety of Home) (serie de fotos: 1980-1983). Impresión sobre gelatina de plata, $245 \mathrm{~mm}$ x $133 \mathrm{~mm}$. Reproducida en Sichel, B. y Krulik, B (dirs.). Lorraine O'Grady. Op. cit., cubierta. 
De Miller y otros dibujantes hemos aprendido que en el cómic menos es más, como suele serlo en otras disciplinas. Véase FIG. 14 (izquierda): la línea es mínima para dejar a la mancha (o al color en su caso) que sugiera las formas. El recurso estaba en cómics como Sherlock Time (1958), de H. G. Oesterheld y Alberto Breccia, diversas obras de Hugo Pratt o el Sin City (1992-2000) de Frank Miller. Al contrario del proceso habitual de entintado (primero las líneas, luego la mancha), Miller entintaba Sin City aplicando las masas de negro con pincel, y solo al final añadía líneas mínimas con plumilla, operando así por sustracción de detalles para apelar a lo que Gombrich llamaba el beholder's share: el observador suplirá lo que el artista ha omitido. ${ }^{31}$ Miller explicaba:
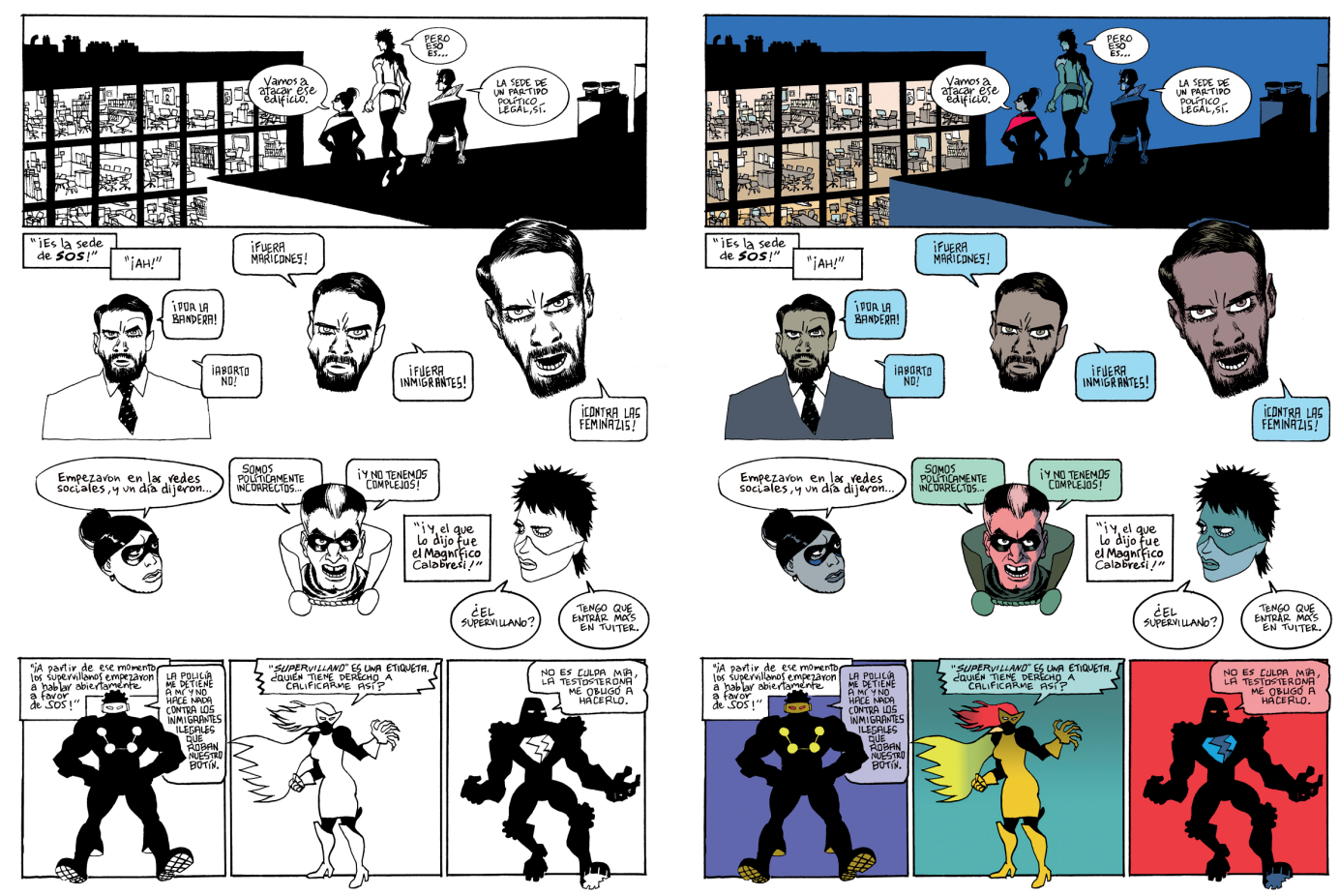

FIG. 14. Proceso para la cuarta página de «Tirana» (2019), línea de tinta y acabado a color.

And then I decided that if the blacks were so important [en Sin City] I would lay them in before I did any linework, and so I reversed the way people usually work. By doing that I was able to see the whole page before I ever picked up the pen, I would just come in with the flat black areas and see what else was needed. And because of that, I was able to reduce the amount of line dramatically. It was really simple, technical things such as those that led me to the breakthrough with Sin City. ${ }^{32}$

31 Gombrich, E. H. Arte e ilusión. Estudio sobre la psicología de la representación pictórica. Madrid, Debate, 2002, p. 286. Traducción de Gabriel Ferrater.

32 Salisbury, M. Artists on Comic Art. Londres, Titan Books, 2000, pp. 169-170. 


\section{Lo obvio y lo obtuso}

«Rosa» (2019) es otra de las historias nuevas para Historias, un acto de justicia con uno de los protagonistas menos desarrollados de El vecino, Rosa, la vecina escritora. Aparecen además dos personajes nuevos, Amaya y Clara, amigas de Rosa, con un diseño inspirado en personas reales para darles rasgos singulares y alejarlos del estereotipo de cómic (FIG. 15, izquierda). En la viñeta final se desarrolla un recurso ya apuntado en blanco y negro en El vecino 3, llevándolo ahora a terreno más «concreto» a través del color: dibujar de repente al personaje clave de la escena, aquí Rosa, en un registro más realista (FIG. 15, derecha). El cómic es básicamente dibujo, no una «cámara de cine». Y el dibujo es flexible, dúctil: permite romper la unidad de estilo si conviene a la narración o añade otra capa de significado (recientemente, Emil Ferris ha convertido el dibujo cambiante en parte sustancial del estilo narrativo de su obra maestra My Favorite Thing Is Monsters [2017]). En esa viñeta de «Rosa» el significado resulta un tanto inefable, como lo es su ambiguo diálogo final; hablamos del pensamiento en imágenes y su lógica paradójica, no verbalizada, que tanto preocupó a Tarkovski. ${ }^{33}$ Las imágenes se resisten al sentido y, como dijo Barthes, a lo obvio se suma un sentido obtuso que no puede traducirse a palabras:
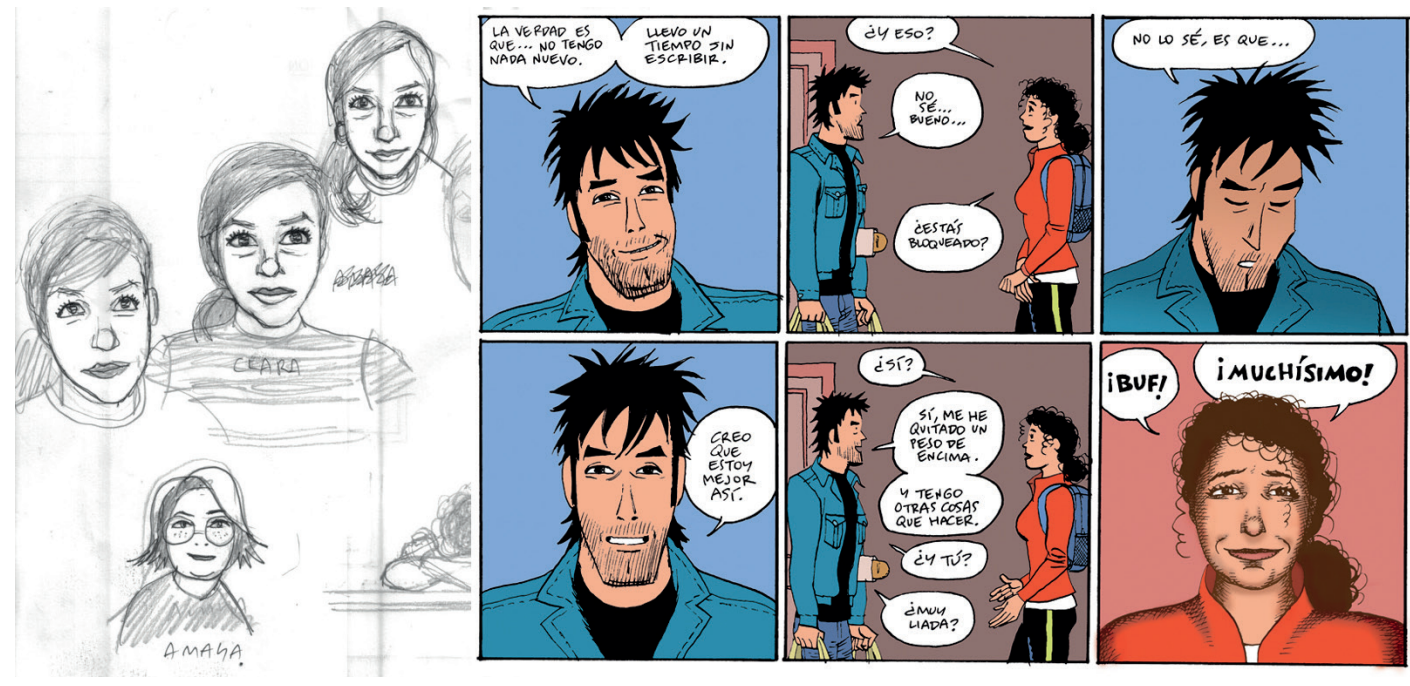

FIG. 15. Izquierda: Bocetos para el diseño de nuevos personajes en «Rosa» (2019) (detalle).

Derecha: detalle de la última página de «Rosa» (2019).

el sentido obtuso es un significante sin significado; por ello resulta tan difícil nombrarlo: mi lectura se queda suspendida entre la imagen y su descripción, entre la definición y la

33 Véase Tarkovski, A. Esculpir en el tiempo. Madrid, Rialp, 2008, pp. 37 y 179. Traducción de Enrique Banús Irusta y J. M. Gorostidi Munguía. 
aproximación. El sentido obtuso no puede describirse porque, frente al sentido obvio, no está copiando nada: ¿cómo describir lo que no representa nada? En este caso es imposible una expresión pictórica en palabras. [...] Lo cual significa que el sentido obtuso está fuera del lenguaje (articulado), pero, sin embargo, dentro de la interlocución. ${ }^{34}$

\section{Comedia de metaficción «espectacular»}

«La película» (2019, realizada para El vecino. Historias) gira en torno a la industria del espectáculo a través de dos protagonistas vecinales, Lola y Javier. Se trata de una farsa cómica: una productora audiovisual va a rodar un largometraje basado en las aventuras de Titán; Lola, periodista, tiene que cubrir el reportaje y visita el plató con Javier, a quien solo le preocupa la posibilidad de cobrar «derechos de autor» porque adaptan su «vida como superhéroe»; el problema es que para reclamar algún tipo de «derechos» tiene que firmar un contrato bajo su identidad civil, que prefiere mantener en secreto. De manera breve pero precisa se ironiza sobre el negocio del espectáculo y su monopolio de las apariencias. Como sostuvo Debord:

El espectáculo se presenta como una enorme positividad indiscutible e inaccesible. No dice más que esto: «lo que aparece es bueno, lo bueno es lo que aparece». La actitud que por principio exige es esa aceptación pasiva que ya ha obtenido de hecho gracias a su manera de aparecer sin réplica, gracias a su monopolio de las apariencias. ${ }^{35}$

En «La película» hay otro juego metaficcional. El guion fue escrito antes de que visitásemos el rodaje de la adaptación audiovisual para Netflix de El vecino (2019), pero la historieta fue dibujada después, usando fotos del set como referencia para la escena de Javier y Lola en el plató. Así, de algún modo duplicamos nuestra experiencia de estar en un decorado tangible, físico, basado en nuestras viñetas, y la traemos de vuelta al universo de ficción original de El vecino, el cómic.

\section{Drawing vs. cartooning}

«No te levantes» (publicada en NSLM n. ${ }^{\circ}$ 15, mayo 2007, el último número de la revista) aborda la enfermedad del padre y las rutinas penosas de la vida en el hospital; como en otras ocasiones, El vecino lleva las vicisitudes de la vida corriente a un mundo en el que existen superhéroes. El objetivo, como se apuntó al comienzo, es contemplar lo ordinario desde esa atalaya extraordinaria con una visión extrañada, distanciada, (tragi)cómica.

${ }^{34}$ Barthes, R. Lo obvio y lo obtuso. Imágenes, gestos, voces. Barcelona, Paidós, 1986, , p. 61. Traducción de C. Fernández Medrano.

35 Debord, G. La sociedad del espectáculo. Valencia, Pre-Textos, 2002, p. 41. Traducción de José Luis Pardo. 
«No te levantes», cronológicamente la primera de las historietas cortas de El vecino que realizamos, adelantaba el dibujo de "caricatura de línea clara» predominante en nuestras historias breves posteriores de $E l$ vecino. En retrospectiva, la razón parece obvia: la historia, de una sola página, tiene veinticuatro miniviñetas, a menudo con el mismo plano/encuadre repetido para evocar las horas muertas y la repetición de la rutina de hospital (el padre de Javier/Titán está enfermo, ingresado). En unos marcos tan pequeños es necesario usar un registro gráfico sintético, muy legible, hasta el punto en que el dibujo se convierte en mero «signo» (FIG. 16). El equivalente a una tipografía, como diría Chris Ware, responsable por otra parte de recuperar y desarrollar este tipo de grafismo y diseño de página, frecuente en las dominicales del cómic de prensa norteamericano de las primeras décadas del siglo xx de autores como Winsor McCay, Charles Forbell, Herriman, Frank King y otros, antes de la influencia hegemónica del cine.
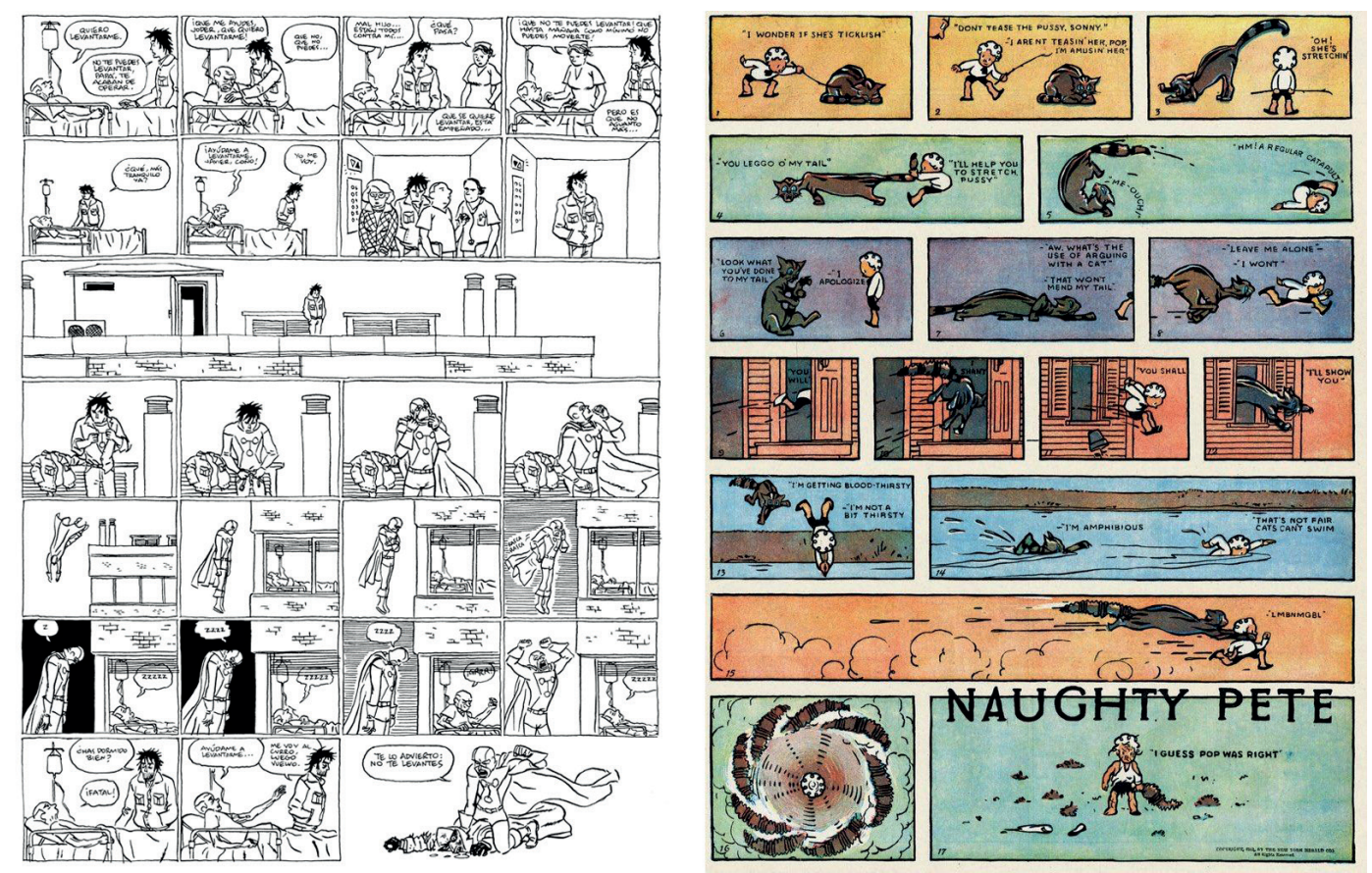

FIG. 16. Izquierda, la página única de «No te levantes» (2007).

Derecha: Charles Forbell, página dominical de Naughty Pete, en The New York Herald (1913). Compárese este modelo del cómic de prensa de principios del siglo $\mathrm{xx}$ con el modelo «cinematográfico» (FIG. 7). 
Hace unos años, Ware exponía sus reflexiones sobre lo que él considera el dibujo más apropiado para sus cómics, distinguiendo entre dibujo y cartooning. ${ }^{36} \mathrm{El}$ drawing, para Ware, es lo que practica en los apuntes del natural de sus cuadernos de bocetos, «una práctica relacionada con la visión y la captación de la naturaleza, dentro de un esquema representacional de raíz academicista. Para el cómic, sin embargo, prefiere el cartoon, la caricatura, el "signo gráfico"». ${ }^{37}$ Así, el dibujo de línea típico del cartooning, habitual en el cómic y el cine animado, funcionaría como una analogía de los procesos de percepción visual y memoria con los que recordamos y conceptualizamos el mundo. Según Ware, la «esencia» de los cómics estribaría en el proceso de leer imágenes, no solo mirarlas, y las líneas negras del cartoon — no existen líneas negras en la naturaleza - serían aproximaciones visuales al modo en que recordamos ideas generales; bajo ellas Ware emplea color naturalista para sugerir al mismo tiempo una experiencia perceptiva. ${ }^{38}$ En otra ocasión, Ware afirmó acerca del tipo de dibujo que considera más apropiado para sus cómics: «Fundamentally you're better off using ideograms rather than realistic drawings. [...] There's a vulgarity to showing something as you really see it and experience it. It sets up an odd wall that blocks the reader's empathy.» ${ }^{39}$

Frente al drawing, un tipo de dibujo artístico que atiende más a la mirada y al detalle preciso naturalista, y que trata más del detalle y la mirada, el cartooning intenta hacer funcionar una historia con dibujos como símbolos, cuya información es más rudimentaria o conceptual..$^{40} \mathrm{El}$ dibujo de línea —afirmaba ya en el siglo xIX uno de los «padres» del cómic moderno, Rodolphe Töpffer- es un puro simbolismo convencional..$^{41}$ En pocas palabras, «el dibujo es para ver y el cartooning para leer». ${ }^{42}$ En su día nos acogimos a esta teoría y por eso el dibujo en El vecino es, como regla predominante, caricaturesco y sintético. Esto no impide introducir cambios de registro, incluso de carácter realista/ilusionista, en función del tono de la historia (como en «Una nueva

${ }^{36}$ La palabra cartoon es de traducción problemática y tiene varias acepciones dependiendo del contexto. Puede aludir a chistes gráficos, al cómic en general, a los dibujos animados del cine, o a un estilo de dibujo caricaturesco. En general, cartoon «se relaciona con la producción de imágenes de estilo no realista dibujadas en medios de masas». GARcía, S. «Chris Ware: estrategias para un cómic nuevo», en Mundaiz n. 76 (2008), p. 9.

37 Ibid., p. 21.

38 Bengal, R. «On Cartooning», en POV (2006). Citado y traducido en PÉrez, P. «El dibujo / El dibujo", en Con $C$ de arte, 15 de julio de 2008. Disponible en: http://concdearte.blogspot. com/2008/07/el-dibujo-el-dibujo.html

39 Raeburn, D. Op. cit., p. 18.

40 Groth, G. «Chris Ware», en The Comics Journal n. 200 (1997), p. 131.

${ }^{41}$ Töpffer, R. Essai de Physiognomonie, en Gutenberg.ca (2012) [1845]. Disponible en: https://www. gutenberg.ca/ebooks/toeppferr-physiognomonie/toeppferr-physiognomonie-00-h-dir/toeppferr-physiognomonie-00-h.html

${ }^{42}$ Entrevistado en PÉrez, P. «Chris Ware. Inventando el cómic futuro», en Rockdelux n. ${ }^{\circ} 283$ (2010), p. 47. 
oportunidad», en ese caso ya comentado para copiar el estilo de dibujantes del comic book clásico como John Romita Jr., FIG. 7) o e incluso de una escena o viñeta específica. Dependiendo del caso, puede que la caricatura no sea la mejor elección para la representación, porque el personaje o momento narrativo exige una representación «realista» (FIG. 14, última viñeta), lo que genera un distanciamiento en el lector: la paradoja del dibujo de realismo ilusionista dentro de la secuencia de cómic es que crea una distancia de extrañamiento y mitifica lo representado, lo vuelve irreal. ${ }^{43}$

\section{Superhéroes-villanos en clave alegórica}

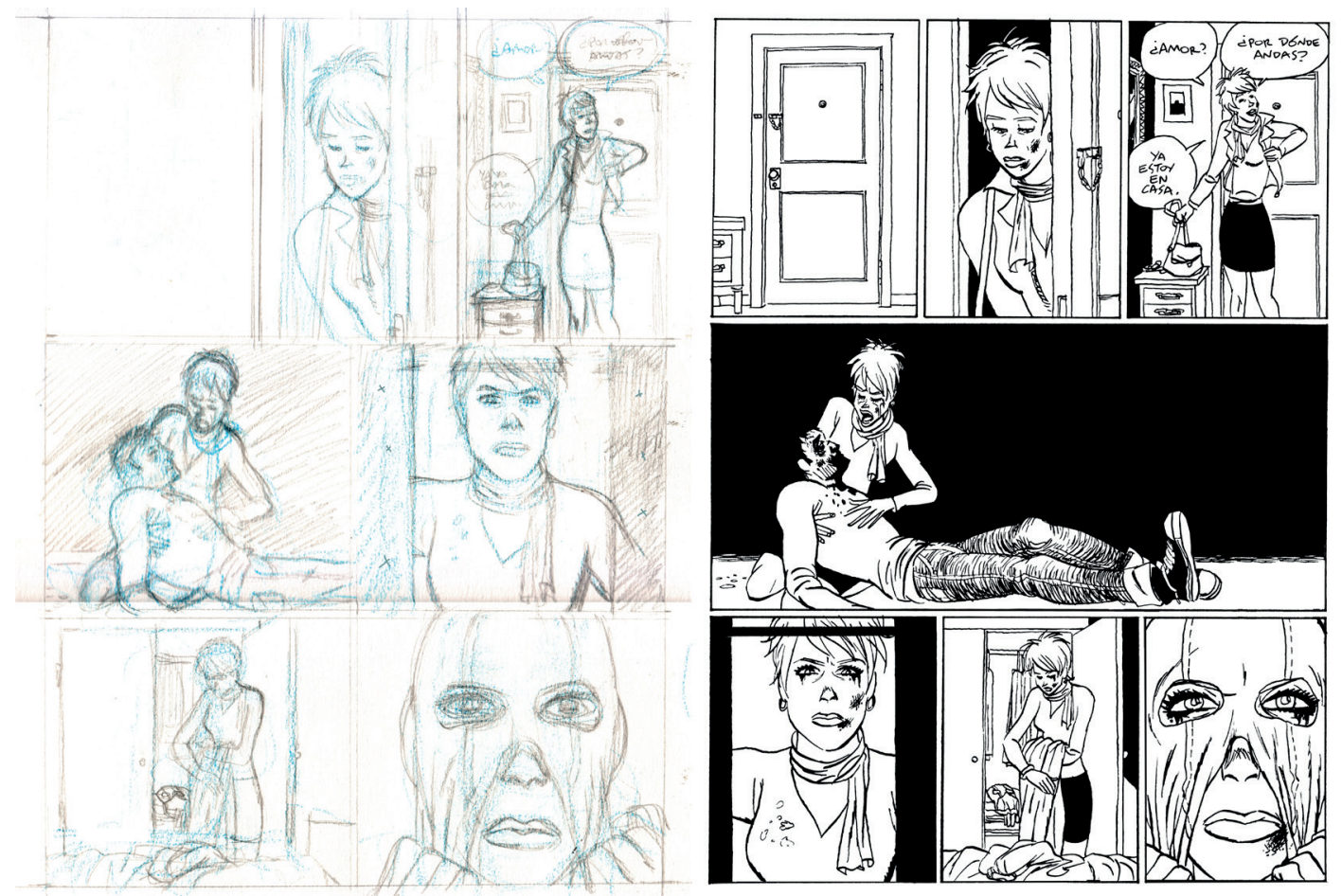

FIG. 17. La penúltima página de «Flash

Diamond» (2011), boceto y acabado.

«Flash Diamond» (2011) es una historieta que realizamos para el cómic colectivo que acompañaba el DVD de Diamond Flash (2011). Carlos Vermut, director y guionista del filme, nos invitó a participar y aceptamos encantados para realizar nuestro homenaje a su debut en el largometraje, una película enigmática, perturbadora e imprevisible. En nuestra historia quisimos evocar en particular el misterio inefable de Diamond Flash, el «super(anti)héroe» de la película de Vermut. El tono de la historia, de algún modo, «pedía» una representación en blanco y negro con abundantes masas

${ }^{43}$ Véase al respecto el convincente estudio de Medley, S. «Discerning Pictures: How We Look At and Understand Images in Comics», en Studies in Comics n. ${ }^{\circ} 1.1$ (2010), pp. 53-70. 
de negro; el color solo se usó en un elemento de la última viñeta. Hay otras viñetas puntuales dibujadas a lápiz (primeras apariciones de Diamond Flash, más «atmosféricas»), en contraste con las líneas de tinta del resto, y un uso estratégico del lenguaje de la ilustración en alguna viñeta, con un mayor grado de simbolismo y síntesis. En la penúltima página (FIG.17), el cambio de diseño final respecto al boceto se hizo para sugerir más «tiempo» narrativo en la cuarta viñeta y darle un mayor énfasis emocional. En la versión definitiva que fue a imprenta, esa cuarta viñeta domina jerárquicamente toda la página.

\section{«El fin»: en otro plano}
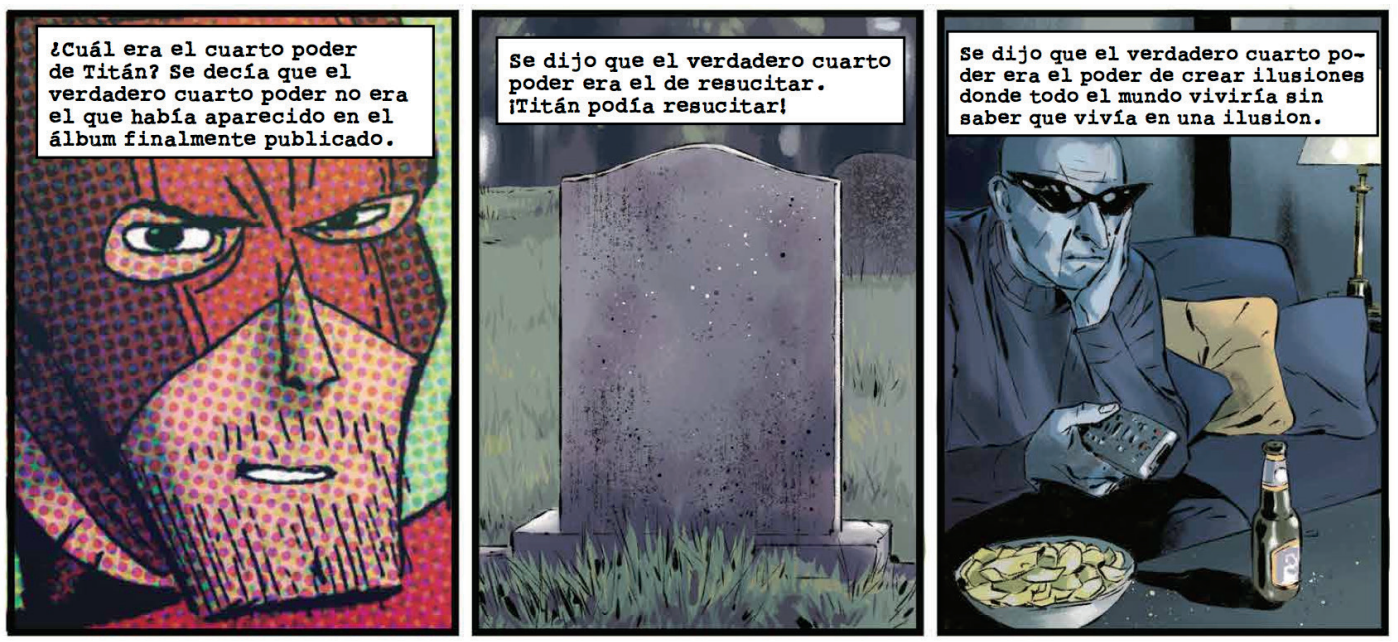

FIG. 18. Detalle de la última página de «El fin» (2019), donde el estilo de Rodrigo Zayas se contrapone con la cita de la primera viñeta, extraída de «Soy un superhéroe» (reproducida en la FIG. 2).

«El fin» era otra historieta escrita por Santiago García en 2010, que quedó inédita debido a la cancelación de la revista El Manglar. Es una historia, digamos, al margen del canon de El vecino porque transcurre literalmente fuera de la narración de la serie, en un plano «externo». Se trata de una sátira metaficcional que gira en torno al proceso de creación del «último volumen» de El vecino, una historia protagonizada en clave de autoficción por sus «autores» $\mathrm{y}$ «editores». A quien escribe este texto el guion le parecía muy bueno, pero se resistía a dibujarlo por pura superstición (el lector que lea «El fin» entenderá rápidamente la razón). En 2019 Santiago insistió en realizarla para el volumen El vecino. Historias, y la solución que acordamos fue que la dibujara otra persona.

Santiago acudió a Rodrigo Zayas, cuyo registro «fotorrealista» — muy diferente al del autor de estas líneas - es ideal para esta historia. La aleja del universo canónico «ve- 
cinal» y al mismo tiempo aporta un tono (seudo)documental muy acorde con lo que se cuenta, incluyendo «retratos» reconocibles de los autores y editores de El vecino. Zayas, además, se había encargado del concept art y los storyboards para la adaptación televisiva de El vecino para Netflix, lo que vendría a cerrar el círculo metaficcional (algunos personajes tienen el rostro de los actores de dicha adaptación). Por cierto que su trabajo en esta historieta, espléndido, vuelve a demostrar el grado de irrealidad y mitificación que el dibujo fotorrealista introduce en la secuencia de cómic (FIG. 18). En este caso el efecto resulta simplemente perfecto (e irreproducible si la hubiera dibujado quien suscribe).

\section{A modo de conclusión}

Los principales objetivos creativos de El vecino. Historias son los de toda la saga de El vecino, que podríamos resumir ahora en tres. Primero, explorar el significado ideológico y psicopolítico de determinados clichés de la ficción moderna, en particular de los superhéroes. Por ello en determinadas escenas se recrean dichos clichés para transformarlos en material resonante que «revele» la verdad psicológica impronunciable e indefinible escondida en esos tópicos de ficción, lo que Žižek denomina la «transubstanciación espiritual de los clichés». ${ }^{44}$ En segundo lugar, y derivado de lo anterior, cuestionar ciertos temas implícitos en los superhéroes, como la legitimidad de la violencia y el poder, mediante el desplazamiento de significado de sus símbolos habituales. En tercer lugar, abordar temas cotidianos desde la perspectiva «extrañada» que supone un universo de ficción costumbrista donde existen los superhéroes, e investigar aspectos formales del lenguaje del cómic para plantear el uso que damos por hecho de los mismos. Para esto último, como se ha expuesto, recuperamos recursos formales en desuso (textos de apoyo de narrador, bocadillos de pensamiento, colores expresivos antinaturalistas del cómic tradicional, etc.) y formatos hoy obsoletos como la tira de prensa. En este sentido, si una tendencia frecuente - en el cómic y otras disciplinas - es la de ocultar el artificio de la representación para facilitar la inmersión del espectador/lector, en El vecino. Historias dicho artificio se revela en abundantes ocasiones, señalando la condición de ficción de la obra. Esta ironía autorreflexiva implica, por supuesto, exponer el marco representativo ante el lector. De ahí procede también la negación del estilo que hay en este volumen, empleando estilemas diferentes según cada historieta, a veces incluso dentro de la misma historia.

Podemos concluir, a modo de recapitulación, exponiendo el proceso de creación de la cubierta de El vecino. Historias. Para el concepto principal partimos de una tradición concreta del cómic, la de fachadas de edificios en las que los apartamentos son tam-

44 Žı̌̌̇K, S. Lacrimae rerum. Ensayos sobre cine moderno y ciberespacio. Barcelona, Debate, 2006, p. 171. Traducción de Ramon Vilà Vernis.. 
bién viñetas de la página (FIG.19), tradición recreada por Chris Ware en obras como Building Stories (2012).
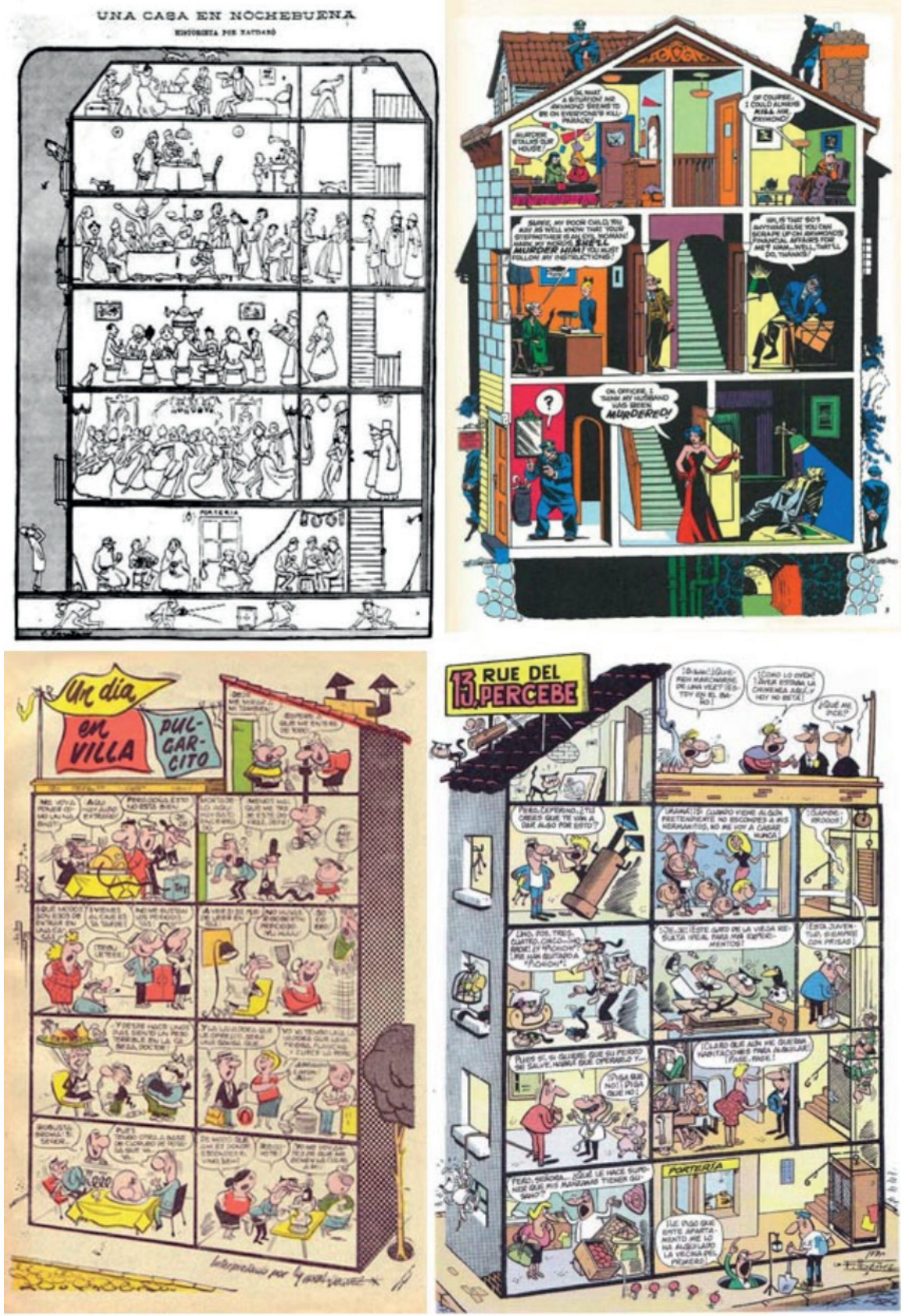

FIG. 19. Joaquim Xaudaró, «Una casa en Nochebuena» (1902); Will Eisner, «The Spirit: School for Girls» (1947); Vázquez, «Un día en Villa Pulgarcito» (1959); Francisco Ibáñez, 13, Rue del Percebe (1961). 


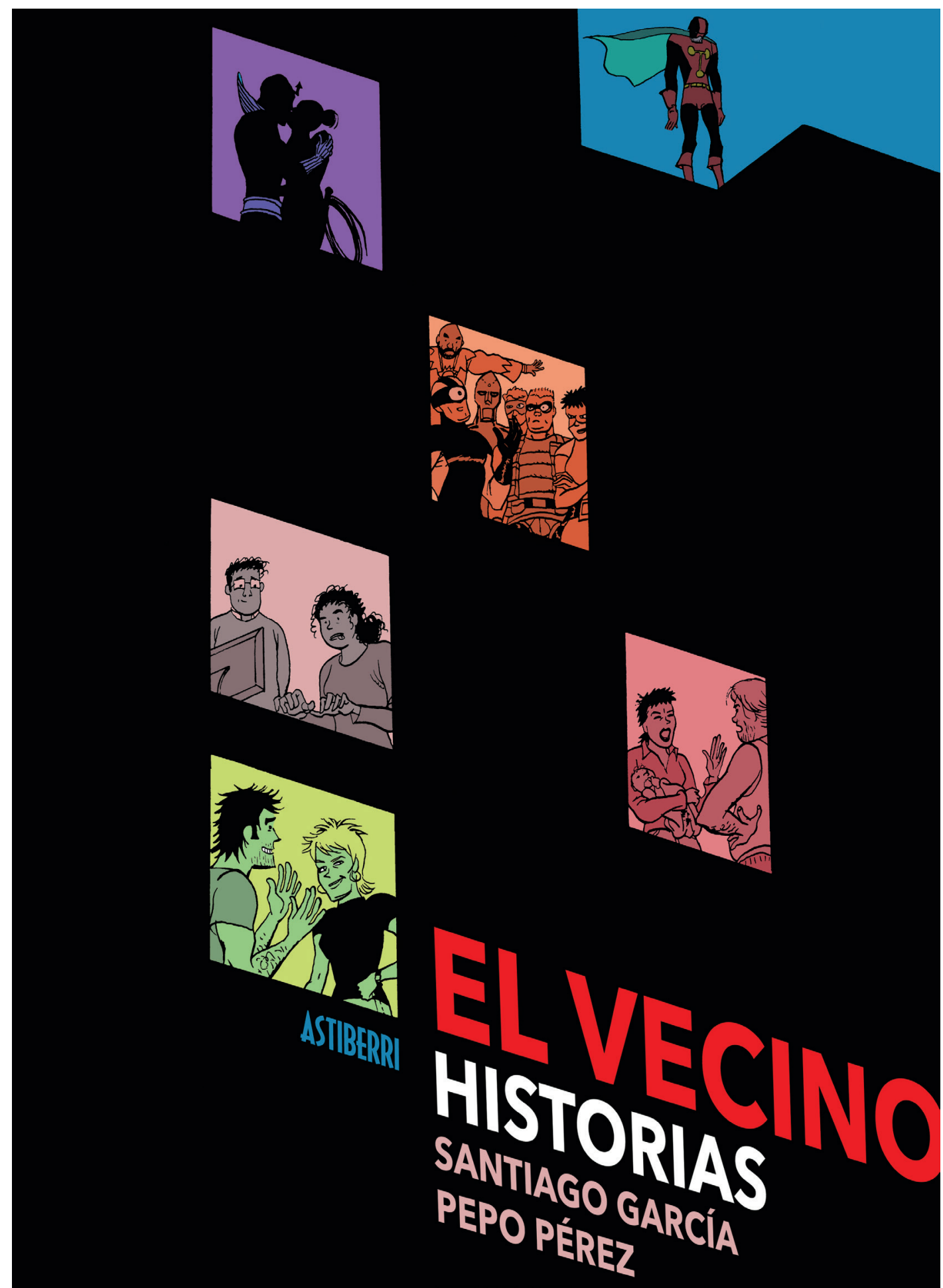

FIG. 20. Cubierta para El vecino. Historias (2019). 
Cada ventana-viñeta de la cubierta (FIG. 20), cada marco narrativo, nos permite asomarnos al interior del «edificio» que es el cómic, sugiriendo las diferentes «historias» que alberga cada «marco». Desde una de esas ventanas-viñetas-marcos narrativos, la mirada de Lola se dirige no a Javier sino al espacio del espectador, el afuera de la ventana de representación, un recurso que analizamos bajo la luz de algunos estudios sobre Las meninas de Velázquez.45

Cada ventana-viñeta está además, deliberadamente, en un «plano» diferente, de color e incluso de perspectiva. El gutter, blanco normalmente, aquí es negro para crear la ilusión de «fachada»; el gutter siempre origina huecos que fuerzan al espectador a completar el acontecimiento entre ellos. El espectador ideal, consciente de las elipsis, intentará reconstruir todo lo que falta, generando con su imaginación una co-ficción. Algunos personajes se repiten en distintas ventanas, y por tanto están en diferente espaciotiempo, algo que permite la simultaneidad por contigüidad del panóptico que es la página de cómic.

Esta cubierta, además, evoca actividad nocturna para sugerir el espíritu de nuestra época. Es de noche pero todo el mundo está activo, no solo el superhéroe «allá arriba», también los vecinos de «aquí abajo». Un tiempo 24/7, propio de la sociedad digital, que ha erosionado gradualmente nuestras horas de sueño hasta derivar en una especie de sleep mode. ${ }^{46} \mathrm{Nada}$ está del todo apagado, nunca hay un estado real de reposo dentro de una dinámica del capitalismo tardío para obtener beneficio de todas las actividades humanas, veinticuatro horas del día / siete días por semana, eliminando la línea entre lo público y lo privado.

${ }^{45}$ Véanse Foucault, M. Las palabras y las cosas. Una arqueología de las ciencias humanas. Madrid, Siglo XXI, 2006, pp. 14-15. Traducción de Elsa Cecilia Frost; SтоіснітA, V. I. La invención del cuadro. Arte, artifices y artificios en los orígenes de la pintura europea. Barcelona, Ediciones del Serbal, 2000, pp. 238-240. Traducción de Anna María Coderch.

${ }^{46}$ Crary, J. 24/7. Late Capitalism and the Ends of Sleep. Londres / Nueva York, Verso, 2013, pp. 11-13. 


\section{Bibliografía}

Altarriba, A. «La historieta, un medio mutante», en Quimera n. 293 (2008), pp. 48-55. Disponible en: http://www.antonioaltarriba.com/la-historieta-un-medio-mutante/

Barthes, R. Lo obvio y lo obtuso. Imágenes, gestos, voces. Barcelona, Paidós, 1986. Traducción de C. Fernández Medrano.

Benet, Vicente J. La cultura del cine, Barcelona, Paidós, 2004.

Bengal, R. «On Cartooning», en POV (2006). Citado y traducido en Pérez, P. «El dibujo / El dibujo», en Con C de arte, 15 de julio de 2008. Disponible en: http:// concdearte.blogspot.com/2008/07/el-dibujo-el-dibujo.html

Castro Flórez, F. Estética de la crueldad. Madrid, Fórcola, 2019.

Clowes, D. «The Death-Ray», en Eightball n. 23 (2004).

Сово, C. у Umbría, A. «Last Supper / Late Nerws. Conversación entre Chema Cobo y Ana Umbría», en Сово, C. Out of Frame. Málaga, CAC Málaga, 2009, pp. 25-38.

Coogan, P. «Genre: Reconstructing the Superhero in All-Star Superman», en Smith, M.J. y Duncan, R. (eds.), Critical Approaches to Comics. Theories and Methods. Nueva York, Routledge, 2012, pp. 203-220.

Crary, J. 24/7. Late Capitalism and the Ends of Sleep. Londres / Nueva York, Verso, 2013.

Debord, G. La sociedad del espectáculo. Valencia, Pre-Textos, 2002. Traducción de José Luis Pardo.

Donnelly, S. «Stephen King on His Comics' Debut», en The Daily Beast, 14 de marzo de 2010. Disponible en: https://www.thedailybeast.com/blogs-and-stories/2010-03-14/stephen-king-on-his-comics-debut/2

Eco, U. Apostillas a El nombre de la rosa. Barcelona, Lumen, 1985. Traducción de Ricardo Pochtar.

Ferris, E. My Favorite Thing Is Monsters. Seattle, Fantagraphics, 2017.

Fisher, M. Lo raro y lo espeluznante. Barcelona, Alpha Decay, 2018. Traducción de Núria Molines. 
Foucault, M. Las palabras y las cosas. Una arqueología de las ciencias humanas. Madrid, Siglo XXI, 2006. Traducción de Elsa Cecilia Frost.

García, S. «Chris Ware: estrategias para un cómic nuevo», en Mundaiz n. ${ }^{\circ} 76$ (2008), pp. 9-42.

—La novela gráfica. Bilbao, Astiberri, 2010.

García, S. y Pérez, P. El vecino 1. Bilbao, Astiberri, 2004.

-El vecino 2. Bilbao, Astiberri, 2007.

-El vecino 3. Bilbao, Astiberri, 2009.

—El vecino. Historias. Bilbao, Astiberri, 2019.

Gombrich, E. H. Arte e ilusión. Estudio sobre la psicología de la representación pictórica. Madrid, Debate, 2002. Traducción de Gabriel Ferrater.

Groensteen, T. The System of Comics. Jackson, University Press of Mississippi, 2007. Traducción de Bart Beaty y Nick Nguyen.

- Parodies. La bande dessinée au second degré. París, Skira Flammarion / Musée de la Bande Dessinée, 2010.

Groth, G. «Chris Ware», en The Comics Journal n. 200 (1997), pp. 118-178.

Gubern, R. El lenguaje de los comics. Barcelona, Edicions 62, 1972.

Haraway, D. J. «A Cyborg Manifesto: Science, Technology, and Socialist-Feminism in the Late Twentieth Century", en Simians, Cyborgs, and Women: The Reinvention of Nature. Nueva York, Routledge, 1991, pp. 149-181.

Harvey, R. C. Meanwhile... A Biography of Milton Caniff. Seattle, Fantagraphics, 2007.

Jan y Efepé. Superlópez: El supergrupo. Barcelona, Bruguera, 1980.

-Superlópez: ¡Todos contra uno, uno contra todos! Barcelona, Bruguera, 1981.

Keats, J. «Lamia», en Barbleby.com (2015) [1819]. Disponible en: https://www. bartleby.com/126/36.html 
Lee, S., Dit ko, S. y Romita, J. The Amazing Spider-Man. Marvel Masterworks Vol. 4. Nueva York, Marvel Comics, 2010.

Lee, S. y Romita, J. The Amazing Spider-Man. Marvel Masterworks Vol. 5. Nueva York, Marvel Comics, 2010.

-The Amazing Spider-Man. Marvel Masterworks Vol. 6. Nueva York, Marvel Comics, 2011.

Leth, J. y Von Trier, L. De fem benspaend (Las cinco condiciones). [Largometraje de cine]. Dinamarca, Peter Aalbæk, Jensen Vibeke \& Windeløv Wajnbrosse Productions, 2003.

Lynch, D. Lost Highway. [Largometraje de cine]. Francia / Estados Unidos, CiBy 2000 y Asymmetrical Productions, 1997.

—Mulbolland Drive. [Largometraje de cine]. Estados Unidos, Les Films Alain Sarde, Asymmetrical Productions, Babbo Inc., Canal+ y The Picture Factory, 2001.

Lynch, D. y McKenna, K. Espacio para soñar. Barcelona, Reservoir Books, 2018. Traducción de Aurora Echevarría y Luis Murillo.

McCloud, S. Entender el cómic. El arte invisible. Bilbao, Astiberri, 2005. Traducción de Enrique S. Abulí.

Medley, S. «Discerning Pictures: How We Look At and Understand Images in Comics», en Studies in Comics n. 1.1 (2010), pp. 53-70.

Miller, F. Sin City (11 vols.). Milwaukie, Dark Horse, 1992-2000.

Miller, F., Janson, K. y Varley, L. Batman: The Dark Knight Returns. Nueva York, DC Comics, 1986.

Miller, F., y Varley, L. Batman: The Dark Knight Strikes Again (DK2). Nueva York, DC Comics, 2002.

Mulvey, L. «Visual Pleasure and Narrative Cinema», en Braudy, L. y Cohen, M. (eds.). Film Theory and Criticism: Introductory Readings. Nueva York, Oxford University Press, 1999, pp. 838-844.

Oesteherld, H. G., y Breccia, A. Sherlock Time. Buenos Aires, Colihue, 1999. 
Prat, H. Corto Maltés, diversos volúmenes. Madrid, Nueva Frontera; Barcelona, Norma, 1972-1992.

PÉRez, P. «Chris Ware. Inventando el cómic futuro», en Rockdelux n. 283 (2010), pp. 46-47.

— $\mathrm{E} 1$ discurso interior en los cómics de Frank Miller», en Ítaca n. ${ }^{0} 1.3$ (2013), pp. 97-147.

Puelles Romero, L. Mirar al que mira. Teoría estética y sujeto espectador. Madrid, Abada, 2011.

Raeburn, D. Chris Ware. New Haven, Yale University Press, 2004.

Ramírez, J. A. El objeto y el aura. (Des)orden visual del arte moderno. Madrid, Akal, 2009.

Rodley, C. (ed.). David Lynch por David Lynch. Barcelona, Alba, 1998. Traducción de Manu Berástegui y Javier Lago.

Rorty, R. Contingency, Irony, and Solidarity. Cambridge, Cambridge University Press, 1989.

Rubert de Ventós, X. El cortesano y su fantasma. Barcelona, Destino, 1991.

Salisbury, M. Artists on Comic Art. Londres, Titan Books, 2000.

Santamaría, A. Narración o barbarie. Vitoria-Gasteiz, Sans Soleil, 2017.

Sichel, B. y Krulik, B. (dirs.). Lorraine O'Grady. Aproximación inicial / Initial Recognition. Sevilla, Consejería de Cultura Junta de Andalucía / Centro Andaluz de Arte Contemporáneo, 2016.

Snyder, S., King, S. y Albuguerque, R. American Vampire, vol. 1. Nueva York, Vertigo/DC Comics, 2011.

Stoichita, V. I. La invención del cuadro. Arte, artífices y artificios en los orígenes de la pintura europea. Barcelona, Ediciones del Serbal, 2000. Traducción de Anna María Coderch.

Töpffer, R. Essai de Physiognomonie, en Gutenberg.ca (2012) [1845]. Disponible en: https://www.gutenberg.ca/ebooks/toeppferr-physiognomonie/toeppferr-physiognomonie-00-h-dir/toeppferr-physiognomonie-00-h.html 
Tarkovski, A. Esculpir en el tiempo. Madrid, Rialp, 2008. Traducción de Enrique Banús Irusta y J. M. Gorostidi Munguía.

Vermut, C. Diamond Flash. [Largometraje de cine]. España, Silvestre López, 2011.

Vizuete, J. El experimento. Barcelona, Glénat, 2009.

Ware, C. Building Stories. Nueva York, Pantheon, 2012.

ŽıžeK, S. Lacrimae rerum. Ensayos sobre cine moderno y ciberespacio. Barcelona, Debate, 2006. Traducción de Ramon Vilà Vernis. 